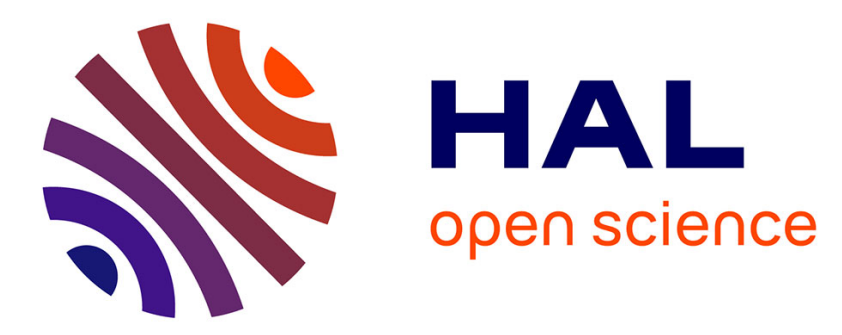

\title{
Supramolecular redox-responsive substrate carrier activity of a ferrocenyl Janus device
}

Shengdong Mu, Qiangjun Ling, Xiong Liu, Jaime Ruiz, Didier Astruc, Haibin $\mathrm{Gu}$

\section{- To cite this version:}

Shengdong Mu, Qiangjun Ling, Xiong Liu, Jaime Ruiz, Didier Astruc, et al.. Supramolecular redoxresponsive substrate carrier activity of a ferrocenyl Janus device. Journal of Inorganic Biochemistry, 2019, 193, pp.31 - 41. 10.1016/j.jinorgbio.2018.12.018 . hal-03485692

\section{HAL Id: hal-03485692 \\ https://hal.science/hal-03485692}

Submitted on 20 Dec 2021

HAL is a multi-disciplinary open access archive for the deposit and dissemination of scientific research documents, whether they are published or not. The documents may come from teaching and research institutions in France or abroad, or from public or private research centers.
L'archive ouverte pluridisciplinaire HAL, est destinée au dépôt et à la diffusion de documents scientifiques de niveau recherche, publiés ou non, émanant des établissements d'enseignement et de recherche français ou étrangers, des laboratoires publics ou privés.

\section{(ㄷ)(1) $\$$}

Distributed under a Creative Commons Attribution - NonCommercial| 4.0 International 


\title{
Supramolecular redox-responsive substrate carrier activity of a ferrocenyl Janus device
}

\author{
Shengdong Mu, ${ }^{1,2}$ Qiangjun Ling, ${ }^{1,2}$ Xiong Liu, ${ }^{1,2}$ Jaime Ruiz, ${ }^{3}$ Didier Astruc, ${ }^{3,}{ }^{*}$ Haibin $\mathrm{Gu}^{1,2,{ }^{*}}$ \\ ${ }^{1}$ Key Laboratory of Leather Chemistry and Engineering of Ministry of Education, Sichuan \\ University, Chengdu 610065, China. \\ ${ }^{2}$ National Engineering Laboratory for Clean Technology of Leather Manufacture, Sichuan \\ University, Chengdu 610065, China. \\ ${ }^{3}$ ISM, UMR CNRS No 5255, Univ. Bordeaux, 33405 Talence Cedex, France. \\ E-mail: guhaibinkong@126.com (H.Gu); didier.astruc@u-bordeaux.fr (D. Astruc)
}

\begin{abstract}
Supramolecular Janus compounds have recently attracted increasing attention owing to their dynamic reversible properties, distinct topological structures, and remarkable physicochemical characteristics, e.g., amphiphilicity, heterofunctionality, and high-density of terminal groups. Herein, a new redox-responsive supramolecular Janus device was designed and synthesized involving $\beta$-cyclodextrin and 2-fold ferrocene host-guest interactions. The complex formation was analyzed via one-dimensional ${ }^{1} \mathrm{H}$ NMR and two-dimensional Nuclear Overhauser Enhancement Spectroscopy. $\mathrm{FeCl}_{3}$ and ascorbic acid were used as oxidation and reduction triggers, respectively, to modulate the self-assembly behavior in water through complexation/dissociation of $\beta$-cyclodextrin inclusion compounds resulting from redox-conversion of the ferrocenyl guest moieties. The redox-responsiveness of the obtained supramolecular micelles was studied via scanning electron microscopy and dynamic light scattering. Substrate-loading ability of the supramolecular micelles was confirmed with Rhodamine $B$, and the oxidation of ferrocenyl groups led to the release of the loaded cargos. The present work illustrates a valuable design example of supramolecular Janus systems using the host-guest complexation between $\beta$-cyclodextrin and ferrocenyl structures. The present supramolecular micelle may be used as a promising molecular vehicle for application in the field of stimuli-responsive drug delivery.
\end{abstract}

KEYWORDS: Janus dendrimers; ferrocene; $\beta$-cyclodextrin; host-guest interactions; redox response

\section{INTRODUCTION}

Janus molecules or devices are asymmetric molecules or macromolecules containing two distinct hemispheres, i.e. with distinct sizes and functionalities. They have recently attracted the specific attention of scientists in various research fields including macromolecular chemistry [1], molecular materials [2,3] and biomedicine [4]. The reported Janus derivatives were innovatively applied in various fields such as thermal actuators [5], ionic liquids [6], catalysis [7], light capture [8], bioimaging [9], optoelectronics [10,11] and drug delivery [12-16]. Unlike conventional symmetric molecules [17], Janus molecules are normally constructed using two distinct hemispheres with different sizes and functionalities, featuring 
asymmetric structures [1-4].

Owing to their dynamic nature, various supramolecular interactions including hydrogen bonding [18], host-guest complexes [19-21], or metal complexation [22-24] have been widely investigated in macromolecular chemistry and materials in order to enable stimuli-responsive properties. The redox-sensitive host-guest complexation between $\beta$-cyclodextrin ( $\beta-C D$ ) and ferrocene ( $F c)$ derivative has been first reported in the mid 1980's [25-27], reviewed [28,29] and applied to smart redox devices such as molecular machines [29] and self-healing materials [29,30]. Recently Schmidt et al. have described a redox- and thermo-responsive gated supramolecular star polymers by using the host-guest complexation of a 6-fold $\beta$-CD functionalized core molecule and RAFT-derived Fc end modified by poly( $\mathrm{N}, \mathrm{N}$-dimethylacrylamide) (PDMA) and poly $(\mathrm{N}, \mathrm{N}$-diethylacrylamide) (PDEA) linear polymers [31]. Furthermore, $\beta$-CD-modified G5 poly(amidoamine) (PAMAM) and adamantane (Ad)-functionalized G3 PAMAM dendrimers with amine termini were synthesized by Shen and Shi et al [32] and used to fabricate core-shell tecto dendrimers based on the supramolecular host-guest complexation between $\beta-C D$ and Ad units. These supramolecular devices were effective vehicles used for gene transfection [32]. Along this line, of exceptional interest are supramolecular Janus macromolecules that possess the key asymmetry property of Janus derivatives and dynamic supramolecular host-guest interactions for the purpose of tailoring their properties via external stimuli, e.g. self-assembly behavior.

Among various host-guest inclusion complexes, a typical $\beta-C D / F c-b a s e d$ molecular recognition system has been used to fabricate a plethora of supramolecular devices [33-39]. $\beta-C D$ is a cyclic oligosaccharide composed of seven D-glucose repeating units coupled through $\alpha-1,4-$ glucosidic linkages [40-42], and it resembles a truncated-cone construction with hydrophilic outside surface and hydrophobic internal cavity on the truncated cone [40-42]. Especially, $\beta-C D$ is capable of complexing the sandwich-like hydrophobic Fc moiety at an equivalent molar ratio [43-45]. The formed inclusion complex is dissociated after the neutral hydrophobic $\mathrm{Fc}$ is transferred into cationic hydrophilic ferricinium $\left(\mathrm{Fc}^{+}\right)$using chemical oxidants or electrochemical oxidation and recovered upon reduction of $\mathrm{Fc}^{+}$back to its original neutral Fc structure [44]. This unique transition has been utilized to construct various redox-responsive supramolecular systems [46-53]. For example, Zhang and Li et al synthesized Fc modified camptothecin (FC-CPT) via a dithioether bond and methoxy polyethylene glycol containing $\beta-C D$ end (mPEG- $\beta-C D)$. These authors further fabricated Fc-CPT and mPEG- $\beta$-CD-based supramolecular micelles possessing dual redox-responsiveness of reactive oxygen species (ROS) and glutathione (GSH) [54]. These spherical supramolecular micelles in water exhibit hydrophobic inner core and MPEG as a hydrophilic outer shell and show remarkable hyper-fast CPT release under tumor cell redox microenvironment [54]. In human cancer cells, there is a higher amount of ROS (such as $\mathrm{H}_{2} \mathrm{O}_{2}$ ) than normal cells, which may oxidize $\mathrm{Fc}$ into $\mathrm{Fc}^{+}$and thus lead to the release of the loaded drugs [54].

Critically, however, no redox-responsive supramolecular Janus dendrimer system has been fabricated using the oxidation and reduction properties of $F c / \beta-C D$ complexes. Herein, as shown in Scheme 1, a Janus metallodendrimer $\mathbf{1 1}$ was first synthesized by a typical chemo selective coupling route [4] in which two dendrons containing three triethylene glycol (TEG) branches and two Fc termini, respectively, were connected by an ester bond. Fc-terminated 
dendrons have already been designed and shown to introduce remarkable switching properties in macromolecular devices and ensembles [55-60]. The supramolecular Janus molecule $\boldsymbol{\beta}$-CD@11 (Fig. 1) was then fabricated by simply mixing the Fc-containing Janus molecule 11 with $\beta-C D$ host molecules by host-guest complexation between $\beta-C D$ and Fc. The formation of inclusion complex is verified via one-dimensional ${ }^{1} \mathrm{H} N M R$ and two-dimensional nuclear Overhauser enhancement spectroscopy (NOESY). Chemical redox triggers, namely the use of $\mathrm{FeCl}_{3}$ as oxidant and ascorbic acid as reductant, were utilized to control the self-assembly behavior of the Fc-containing supramolecular Janus assembly $\boldsymbol{\beta}-\mathbf{C D} @ 11$ in water via the association/dissociation transition resulting from the redox-conversion of Fc moieties, and the changes of micelles were carefully detected by scanning electron microscopy (SEM) and dynamic light scattering (DLS). Finally, the $\boldsymbol{\beta}$-CD@11 micelles were used as supramolecular carriers to encapsulate Rhodamine $B(R h B)$, and the loaded RhB were released using a chemical oxidation trigger.
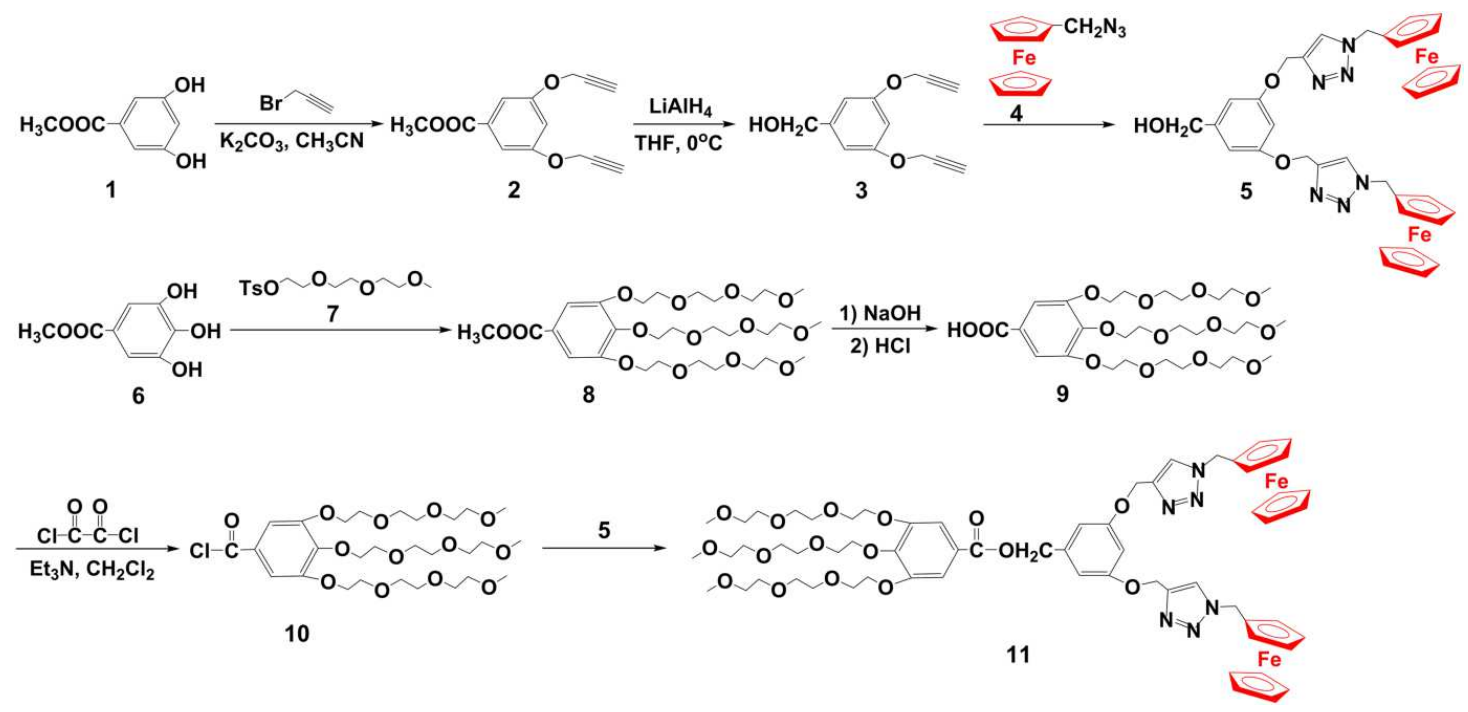

Scheme 1. Synthetic route to the Janus substrate 11.

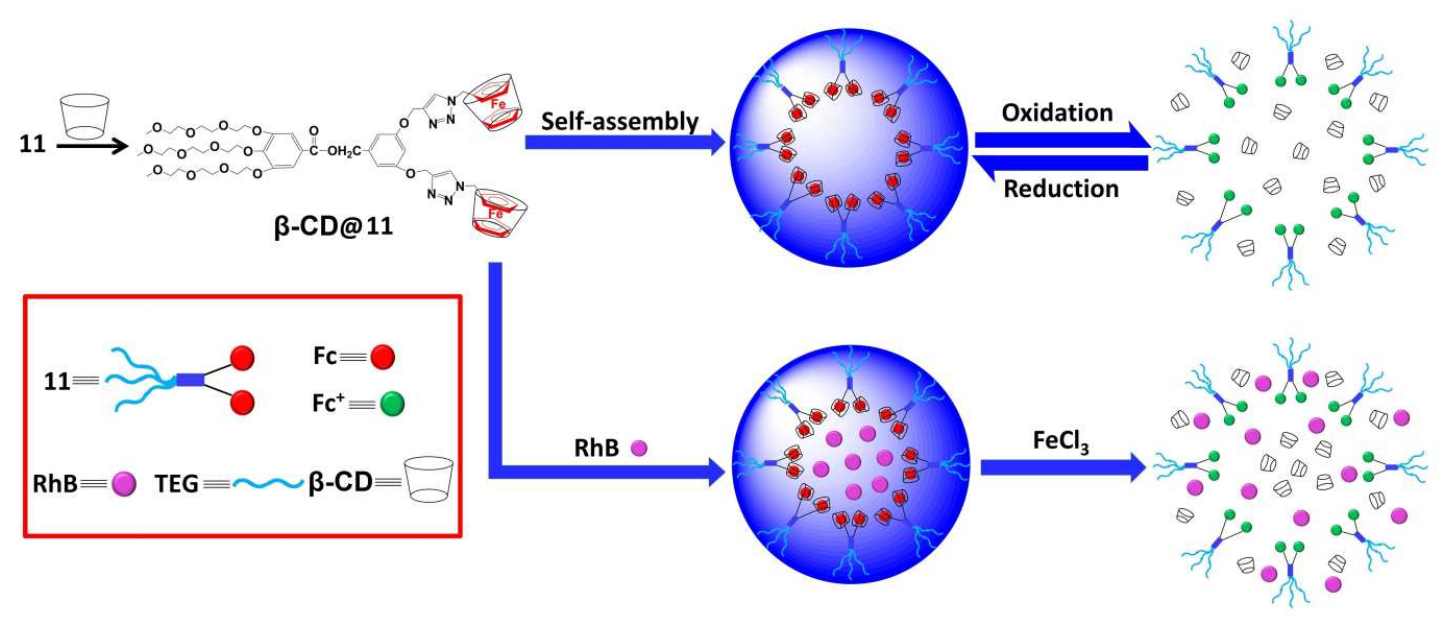

Fig. 1. Schematic formation of the Janus supramolecule $\boldsymbol{\beta}-\mathbf{C D} @ 11$ and its redox-responsive self-assembly, drug-loading and oxidation-triggered release. 


\section{EXPERIMENTAL}

\section{Synthesis of 11}

9 (1.58 g, $2.60 \mathrm{mmol}, 1$ equiv) was dissolved in $25 \mathrm{ml}$ of dry $\mathrm{CH}_{2} \mathrm{Cl}_{2}$, and oxalyl dichloride ( $3.30 \mathrm{~g}, 26.0 \mathrm{mmol}, 10$ equiv) was then injected dropwise into the solution at $0{ }^{\circ} \mathrm{C}$ under $\mathrm{N}_{2}$ atmosphere. After the addition, the obtained mixture was agitated at $r$. t. for $12 \mathrm{~h}$ under $\mathrm{N}_{2}$ atmosphere, and the solvent was then removed in vacuo to yield crude 10 . The product was directly used in the future step, and no further purification was conducted. $5(0.95 \mathrm{~g}, 2.6$ mmol, 1 equiv) and triethylamine ( $2.63 \mathrm{mg}, 3.62 \mathrm{mmol}, 10$ equiv) were added into a Schlenk flask and dissolved in $50 \mathrm{ml}$ of dry $\mathrm{CH}_{2} \mathrm{Cl}_{2} .10 \mathrm{ml}$ of dry $\mathrm{CH}_{2} \mathrm{Cl}_{2}$ was used to dissolve crude 10, and the solution was injected into the Schlenk flask. This mixture was agitated at r. t. for $12 \mathrm{~h}$ under $\mathrm{N}_{2}$ atmosphere, and $50 \mathrm{ml}$ of distilled water was added. This two-phase mixture was separated using a separating funnel. The under phase was washed with $\mathrm{CH}_{2} \mathrm{Cl}_{2}(3 \times 50 \mathrm{ml})$, and all the $\mathrm{CH}_{2} \mathrm{Cl}_{2}$ phase was collected and combined in a flask and washed with brine. The residual water in $\mathrm{CH}_{2} \mathrm{Cl}_{2}$ phase was trapped using anhydrous $\mathrm{Na}_{2} \mathrm{SO}_{4}$. Next, the insoluble salts were removed by suction filtration, and the solvent of obtained filtrate was removed in vacuo to yield a crude product. Finally, its purification was conducted by column chromatography in which the mixture of $\mathrm{CH}_{2} \mathrm{Cl}_{2}$ and methanol $(50: 1, \mathrm{v} / \mathrm{v})$ was used as the eluent. The obtained compound 11 was a yellow-brown solid. Yield: $1.6 \mathrm{~g}, 48 \% .{ }^{1} \mathrm{H}$ NMR (400 $\left.\mathrm{MHz}, \mathrm{CDCl}_{3}, 25{ }^{\circ} \mathrm{C}, \mathrm{TMS}\right), \delta_{\mathrm{ppm}}: 7.52(\mathrm{~s}, 2 \mathrm{H}, 2 \times \mathrm{C}=\mathrm{CH}$ of triazole), $7.29(\mathrm{~s}, 2 \mathrm{H}, \mathrm{ph}), 6.62(\mathrm{~d}, \mathrm{~J}=$ $2.4 \mathrm{~Hz}, 2 \mathrm{H}, \mathrm{ph}), 6.56(\mathrm{t}, J=4.0 \mathrm{~Hz}, 1 \mathrm{H}, \mathrm{ph}), 5.28\left(\mathrm{~s}, 4 \mathrm{H}, 2 \times \mathrm{OCH}_{2}\right), 5.22\left(\mathrm{~s}, 2 \mathrm{H}, \mathrm{COOCH}_{2}\right), 5.11$ $\left(\mathrm{s}, 4 \mathrm{H}, 2 \times \mathrm{NCH}_{2}\right), 4.26(\mathrm{t}, J=3.7 \mathrm{~Hz}, 4 \mathrm{H}, 2 \times \mathrm{sub} . \mathrm{Cp}), 4.22-4.16(\mathrm{~m}, 2 \mathrm{OH}, 3 \times$ ph-OCH, $2 \times$ sub. $\mathrm{Cp}, 2 \times$ free $\mathrm{Cp}$ ), 3.86-3.51 (m, 30H, $\left.3 \times \mathrm{CH}_{2} \mathrm{OCH}_{2} \mathrm{CH}_{2} \mathrm{OCH}_{2} \mathrm{CH}_{2}\right), 3.36(\mathrm{~d}, J=2.0 \mathrm{~Hz}, 9 \mathrm{H}, 3 \times$ $\left.\mathrm{OCH}_{3}\right) .{ }^{13} \mathrm{C}$ NMR $\left(100 \mathrm{MHz}, \mathrm{CDCl}_{3}, 25{ }^{\circ} \mathrm{C}, \mathrm{TMS}\right), \delta_{\mathrm{ppm}}$ : 164.9 (COO), 158.5, 151.3, 142.6, 137.5, 123.8, 108.1, 106.4, 100.5 (ph), 141.7, 121.2 (C of triazole), 79.6 (Cp), 71.3, 70.9, 69.8, 69.6, 69.5, 68.6, 68.1, 68.0, $67.9\left(\mathrm{OCH}_{2}\right.$ and $\left.\mathrm{Cp}\right), 65.4\left(\mathrm{CH}_{2}\right), 61.1\left(\mathrm{CH}_{2}\right), 58.0\left(\mathrm{CH}_{3}\right), 49.1\left(\mathrm{OCH}_{2}\right) . \mathrm{MS}$ (ESI $\mathrm{m} / \mathrm{z}$ ), calcd. for $\mathrm{C}_{63} \mathrm{H}_{80} \mathrm{Fe}_{2} \mathrm{~N}_{6} \mathrm{O}_{16}:$ 1289.05; found: $1289.44\left(\mathrm{M}^{+}\right), 1311.42\left(\mathrm{M}+\mathrm{Na}^{+}\right)$. Selected IR $\left(\mathrm{KBr}, \mathrm{cm}^{-1}\right): 3445 \mathrm{~cm}^{-1}\left(\mathrm{~V}_{\mathrm{OH}}\right), 2924 \mathrm{~cm}^{-1}\left(\mathrm{~V}_{\mathrm{CH} 2}\right), 1430 \mathrm{~cm}^{-1}\left(\mathrm{~V}_{\mathrm{N} 3}\right), 1715 \mathrm{~cm}^{-1}\left(\mathrm{~V}_{\mathrm{C}=\mathrm{O}}\right)$, $1634 \mathrm{~cm}^{-1}\left(\mathrm{v}_{\mathrm{C}=\mathrm{C}}\right), 1105 \mathrm{~cm}^{-1}\left(\mathrm{v}_{\mathrm{C}-\mathrm{O}-\mathrm{C}}\right), 823 \mathrm{~cm}^{-1}\left(\mathrm{VFe}^{\prime \prime}\right)$.

\section{Oxidation of 11 and back Reduction}

11 (23.3 mg, $0.018 \mathrm{mmol}, 1$ equiv) was dissolved in $5 \mathrm{ml}$ of methanol, and $\mathrm{FeCl}_{3}(11.7 \mathrm{mg}$, 0.072 mmol, 4 equiv) was then added to oxidize the $\mathrm{Fc}$ moieties in $\mathbf{1 1} \mathrm{to} \mathrm{Fc}^{+}$cations. The obtained mixture was stirred for $10 \mathrm{~min}$, and the color of the solution changed from original yellow to pale green. In the following reduction experiment, ascorbic acid (13.95 mg, 0.792 mmol, 4.4 equiv) was used as the reductant and added to the above solution. The final solution was then stirred for another $10 \mathrm{~min}$, and its color changed from pale green to yellow.

\section{Self-assembly of $\mathbf{1 1}$ in Water}

The dialysis method [68] was utilized to form micellar aggregates of the Janus substrate. 8.0 $\mathrm{mg}$ of $\mathbf{1 1}$ was thoroughly dissolved in $3 \mathrm{ml}$ of THF, and $1 \mathrm{ml}$ of deionized water was then injected slowly into the solution. Then the mixture was agitated vigorously for $12 \mathrm{~h}$, and the obtained micellar solution was injected into a dialysis bag with molecular weight cutoff 
(MWCO) of $3500 \mathrm{~g} \mathrm{~mol}^{-1}$ for dialysis treatment [68]. The dialysis bag was then immersed into $1000 \mathrm{ml}$ of deionized water for $72 \mathrm{~h}$ in order to completely eliminate the residual THF solvent. During the dialysis process, the dialysate was replaced by fresh deionized water every $5 \mathrm{~h}$ [68]. After dialysis, the total volume of aggregate was completed to $4 \mathrm{ml}$ by adding deionized water, and the final concentration of $\mathbf{1 1}$ was $2.0 \mathrm{mg} \mathrm{ml}^{-1}$.

\section{Preparation of the $\beta$-CD@11 Inclusion Complex Micelles}

$\beta-C D$ (52.8 mg, $0.0465 \mathrm{mmol}, 3$ equiv) and 11 (20 mg, $0.0155 \mathrm{mmol}, 1$ equiv) were initially dissolved using $4 \mathrm{ml}$ and $1 \mathrm{ml}$ of DMF, respectively. The DMF solution of $\beta-C D$ was then injected dropwise into the DMF solution of $\mathbf{1 1}$ under vigorous stirring. The obtained mixture was further heated at $50{ }^{\circ} \mathrm{C}$ for $30 \mathrm{~h} .2 \mathrm{ml}$ of deionized water was then slowly injected into the DMF solution. Then the obtained micellar solution was injected into a dialysis bag with MWCO of $3500 \mathrm{~g} \mathrm{~mol}^{-1}$ for dialysis treatment. The dialysis bag was then immersed into 1000 $\mathrm{ml}$ of deionized water for $72 \mathrm{~h}$ in order to completely eliminate the excess $\beta-C D$ and the residual DMF solvent. After dialysis, the total volume of aggregate was adjusted to $5 \mathrm{ml}$ by adding deionized water, and the final concentration of the inclusion complex was $4.0 \mathrm{mg}$ $\mathrm{ml}^{-1}$.

\section{Redox-response of micelles of 11 and $\beta-C D @ 11$}

The micellar solution of $11\left(2 \mathrm{ml}, 2.0 \mathrm{mg} \mathrm{ml}^{-1}, 0.0031 \mathrm{mmol}, 1\right.$ equiv) was mixed with $\mathrm{FeCl}_{3}$ ( $2.01 \mathrm{mg}, 0.0124 \mathrm{mmol}, 4$ equiv). The obtained mixture was stirred for $10 \mathrm{~min}$, and the color of the micellar solution changed from the original yellow to pale green. In the following reduction experiment, ascorbic acid $(2.40 \mathrm{mg}, 0.0136 \mathrm{mmol}, 4.4$ equiv) was used as the reductant that was added into the above solution. The final solution was then stirred for another $10 \mathrm{~min}$, and its color changed from pale green to yellow. For the micelles of $\boldsymbol{\beta}-\mathrm{CD} @ 11$, a similar procedure was adopted, and the concentration of the micelles $\beta$-CD@11 was $4.0 \mathrm{mg} \mathrm{ml}^{-1}$.

\section{Substrate loading of micelles of $\mathbf{1 1}$ and $\beta-C D @ 11$}

To prepare the RhB-loaded micelles of 11, $5 \mathrm{ml}$ of micellar solution of $11\left(2.0 \mathrm{mg} \mathrm{ml}^{-1}\right)$ and $2.5 \mathrm{mg}$ of RhB were mixed and stirred at $\mathrm{r}$. $\mathrm{t}$. for $12 \mathrm{~h}$. The obtained mixture was then injected into a dialysis bag with MWCO of $3500 \mathrm{~g} \mathrm{~mol}^{-1}$ for dialysis treatment. The dialysis bag was then immersed into $1000 \mathrm{ml}$ of deionized water for $72 \mathrm{~h}$ in order to completely eliminate the excess $\mathrm{RhB}$, and the final concentration of $\mathbf{1 1}$ was $2.0 \mathrm{mg} \mathrm{ml}^{-1}$. The loading content (LC) and encapsulation efficiency (EE) were estimated using the following formulas [16]:

$$
\begin{array}{r}
\text { LC }(\%)=\frac{W_{1}}{W_{2}} \times 100 \% \\
\operatorname{EE~}(\%)=\frac{W_{1}}{W_{3}} \times 100 \%
\end{array}
$$

where $W_{1}, W_{2}$, and $W_{3}$ are the content of the loaded RhB $(\mathrm{mg})$ by micelles of 11 , the added 11 (mg) and the used RhB (mg), respectively, in the process of encapsulation. The value of $W_{1}$ was calculated using the standard curve of RhB (Fig. 9b). A similar procedure was adopted for the RhB-loading of $\beta-C D @ 11$, and the final concentration of 11 was $4.0 \mathrm{mg} \mathrm{ml}^{-1}$. 


\section{In vitro oxidation-triggered substrate release from micelles of 11 and $\beta-C D @ 11$}

$\mathrm{FeCl}_{3}$ was utilized as the oxidizing agent to initiate the release of $\mathrm{RhB}$ from micelles of 11 . Thus $2 \mathrm{ml}$ of the RhB-loaded micelle solution of $\mathbf{1 1}$ was injected into a dialysis bag with MWCO of $3500 \mathrm{~g} \mathrm{~mol}^{-1}$ for dialysis treatment. The dialysis bag was then submerged at $\mathrm{r}$. $\mathrm{t}$. into $10 \mathrm{ml}$ of $\mathrm{FeCl}_{3}$ solution with the concentration of 0 and $1.0 \mathrm{mg} \mathrm{ml}^{-1}$, respectively. The titrations by UV-vis. of the oxidant solution were conducted at various intervals outside the dialysis tube, and the release amount of RhB was measured using the standard curve of RhB. A similar procedure was conducted for the in vitro release of $\mathrm{RhB}$ from the micelle of B-CD@11.

\section{RESULTS AND DISCUSSION}

\section{Synthesis, Structure and Electrochemical Properties of the Janus Substrate 11}

The targeted amphiphilic Janus molecule $\mathbf{1 1}$ is prepared by a typical chemo selective coupling method $[4,69]$. As shown in Scheme 1, two dendrons 5 and $\mathbf{9}$ containing three TEG branches and two Fc termini, respectively, are first synthesized and linked together in the last esterification reaction to yield the new Janus macromolecule 11. Specially, methyl 3,5-dihydroxybenzoate is used as the starting compound to prepare the hydrophobic dendron 5. Its reaction with 3-bromo-1-propyne provides the corresponding methyl 3,5-bis(prop-2-yn-1-yloxy) benzoate 2. $\mathrm{LiAlH}_{4}$ is then utilized to reduce the methyl ester group of $\mathbf{2}$ to hydroxymethyl group. Next, the obtained compound $\mathbf{3}$ bearing two terminal alkynyl groups reacts with azidomethylferrocene 4 to yield hydrophobic dendron $\mathbf{5}$. This copper(I)-catalyzed azide alkyne cycloaddition (CUAAC) "click" reaction is conducted at $r$. $t$. with the aid of the classic Sharpless-Fokin catalyst [70] $\mathrm{CuSO}_{4}+\mathrm{NaAsc}$, and the reaction solvent is the mixture of THF and water $(1: 1, v / v)$. The hydrophilic dendron is synthesized by a known procedure [62], and its reaction with oxalyl chloride leads to 3,4,5-tris(2-(2-(2-methoxyethoxy)ethoxy)ethoxy)benzoyl chloride 10. Finally, the novel Janus substrate $\mathbf{1 1}$ is fabricated by the reaction between the acyl chloride $\mathbf{1 0}$ and the hydrophobic dendron 5 with the aid of trimethylamine. The structure of 11 is verified by ${ }^{1} \mathrm{H}$ (Fig. $2 \mathrm{C}$ ), ${ }^{13} \mathrm{C}$ NMR (Fig. S14) spectroscopy, mass spectrometry (Fig. S15), UV-vis. (Fig. 3a) and FT-IR spectra (Fig. S16).

Fig. 2 provides the ${ }^{1} \mathrm{H}$ NMR spectra $\mathbf{1 1}$ and the two starting dendrons $\mathbf{5}$ and $\mathbf{9}$, and their comparison confirms the structure 11. As shwon in Fig. 2a, the singlet peak at $7.50 \mathrm{ppm}$ corresponds to the two triazolyl protons, and the appearance of this peak demonstrates the success of the "click" reaction of $\mathbf{3}$ with $\mathbf{4}$. For the two Fc moieties in the structure of $\mathbf{5}$, their unique substituted and free cyclopentadienyl (Cp) protons are located at 4.27, 4.21 and 4.17 ppm, and the two peaks at 6.59 and $6.50 \mathrm{ppm}$ are attributed to the phenyl protons. The methyl protons in the $\mathrm{CH}_{2} \mathrm{OH}$ group are found at $4.60 \mathrm{ppm}$, while the two peaks at 5.29 and $5.12 \mathrm{ppm}$ correspond to the $\mathrm{CH}_{2}$ protons close to the triazole rings (Fig. 2a). These data demonstrate the successuful preparation of the Fc-containing dendron $\mathbf{5}$ and its structure. 


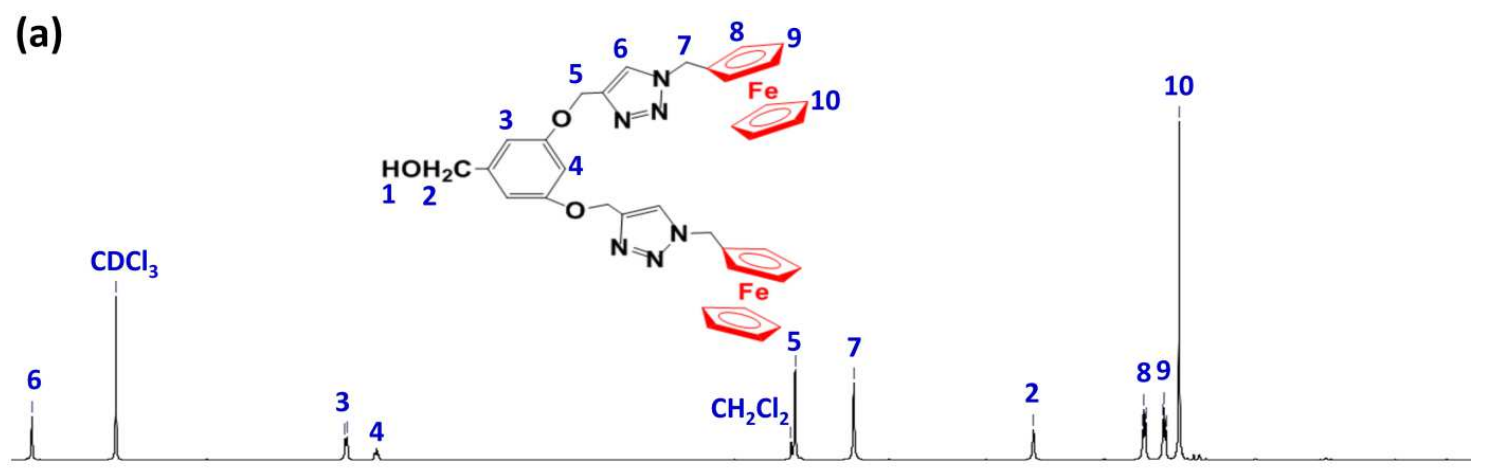

(b)

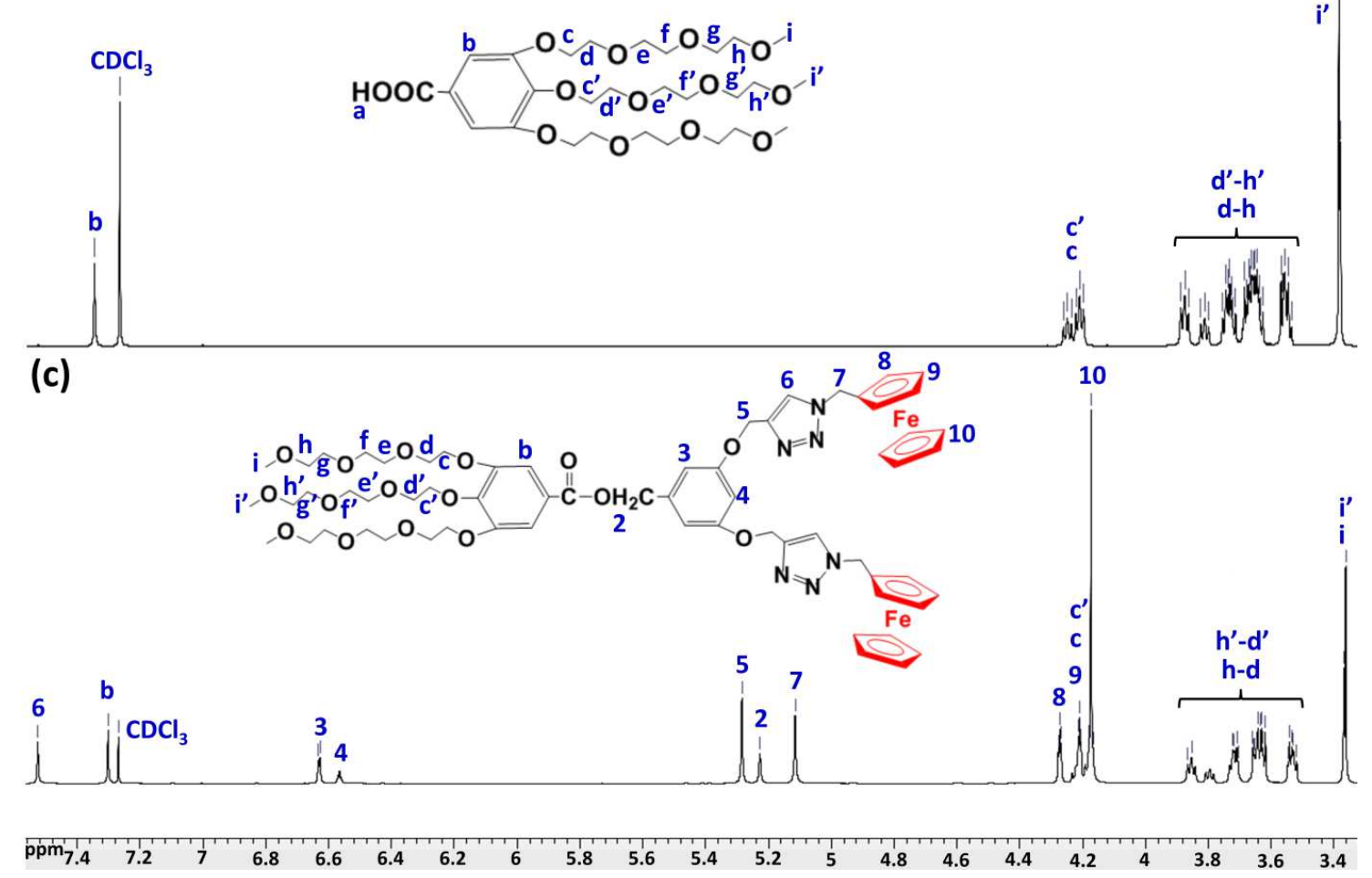

Fig. 2. ${ }^{1} \mathrm{H}$ NMR spectra of 5 (a), 9 (b) and $\mathbf{1 1}(\mathrm{c})$ in $\mathrm{CDCl}_{3}$.

As shown in Fig. 2c, no peak is observed at $4.60 \mathrm{ppm}$ for the $\mathrm{CH}_{2}$ protons close to the $\mathrm{OH}$ group, whereas the new peak at $5.22 \mathrm{ppm}$ is assigned to the $\mathrm{CH}_{2}$ protons connected to the $\mathrm{COO}$ group. The above result clearly confirms the successful esterification reaction between the dendrons 5 and $\mathbf{1 0}$ yielding $\mathbf{1 1}$. The peak at $7.52 \mathrm{ppm}$ arises from the two triazolyl protons and is not shifted when compared to the corrreponding one in Fig. 2a. The multiplet peaks at 4.27-4.16 ppm correspond to the substituted and free $\mathrm{Cp}$ protons in the two Fc units. They are assigned to the six methene protons adjacent to the phenyl ring. For the three TEG structures, their methylene protons are observed at 3.86-3.51 ppm, and their $\mathrm{OCH}_{3}$ protons are found at $3.36 \mathrm{ppm}$. All these results indicate the integrity of the Fc and TEG units and the formation of 11. Fig. S14 shows the ${ }^{13} \mathrm{C} \mathrm{NMR}$ spectrum of $\mathbf{1 1}$ in $\mathrm{CDCl}_{3}$. The $\mathrm{C}=\mathrm{O}$ carbon of the ester group is observed at $164.9 \mathrm{ppm}$, and its adjacent $\mathrm{CH}_{2}$ carbon is found at $49.1 \mathrm{ppm}$. The $\mathrm{C}=\mathrm{C}$ carbons of the triazolyl units are located at 141.7 and $121.2 \mathrm{ppm}$, while the $\mathrm{Cp}$ carbons of Fc moieties are observed at 79.7, 70.9, 69.6 and $67.9 \mathrm{ppm}$, respectively. For the TEG units, their terminal $\mathrm{OCH}_{3}$ carbons are found at $58.0 \mathrm{ppm}$. As shown in Figs. 2c 
and S14, all the other peaks are distinctly designated, and they are in accord with the structure 11. Fig. S15 shows the mass spectrum of $\mathbf{1 1}$ in which a molecular peak is observed at 1289.44 Da in accord with the expected value of $1289.05 \mathrm{Da}$. The UV-vis. spectrum of 11 (Fig. 3a) provides a maximum absorption $\left(\lambda_{\max }\right)$ at $435 \mathrm{~nm}$ attributed to the $d-d^{*}$ transition of the iron center in the Fc groups. The IR spectrum (Fig. S16) also yields helpful evidence for the formation of 11 with bands at $1715 \mathrm{~cm}^{-1}\left(\delta_{\mathrm{c}=0}\right), 1596,1499,1456$ and $1429 \mathrm{~cm}^{-1}\left(\mathrm{v}_{\mathrm{c}=\mathrm{c}}\right.$ of benzene), 1375 and $1330 \mathrm{~cm}^{-1}$ ( $\left.v_{\mathrm{C}-\mathrm{N}}\right), 1206$ and $1106 \mathrm{~cm}^{-1}$ ( $\mathrm{v}_{\mathrm{c}-\mathrm{o}-\mathrm{c})}$ and $823 \mathrm{~cm}^{-1}$ ( $\left.v_{\text {Fell }}\right)$. The targeted Janus dendrimer $\mathbf{1 1}$ is obtained as an orange-yellow thick oil possessing good solubility in usual organic solvents including chloroform, $\mathrm{CH}_{2} \mathrm{Cl}_{2}, \mathrm{THF}, \mathrm{CH}_{3} \mathrm{CN}$, acetone, DMF, methanol and dimethyl sulfoxide (DMSO).
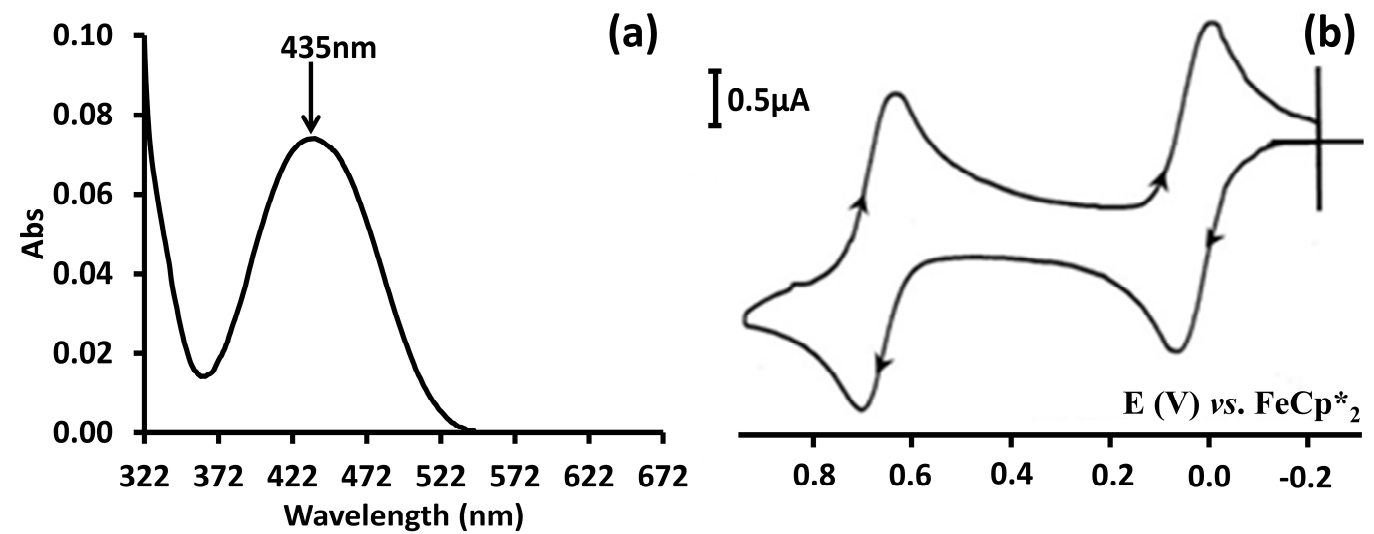

Fig. 3. (a) UV-vis. spectrum and (b) cyclic voltammogram of 11 in $\mathrm{CH}_{2} \mathrm{Cl}_{2}$ at $20{ }^{\circ} \mathrm{C}$. $\mathrm{FeCp} * 2$ is used as the internal reference ( $\mathrm{CV}$ wave at $0.0 \mathrm{~V})$. $\mathrm{Ag}$ is adopted as reference electrode, and $\mathrm{Pt}$ as working and counter electrodes. The scan rate is $0.2 \mathrm{~V} \mathrm{~s}^{-1}$, and the supporting electrolyte is $\left[n-\mathrm{Bu}_{4} \mathrm{~N}\right]\left[\mathrm{PF}_{6}\right](0.1 \mathrm{M})$.

Cyclic voltammetry (CV) is adopted to investigate the electrochemical properties of the Fc-containing Janus compound $\mathbf{1 1}$ using decamethylferrocene, $\left[\mathrm{FeCp}_{2}{ }_{2}\right]$, as the internal reference [63-65]. The CV profile (Fig. 3b) is measured at a scan rate of $0.2 \mathrm{~V} \mathrm{~s}^{-1}$ in $\mathrm{CH}_{2} \mathrm{Cl}_{2}$ at $20{ }^{\circ} \mathrm{C}$ under $\mathrm{N}_{2}$ atmosphere using $\left[n-\mathrm{Bu}_{4} \mathrm{~N}\right]\left[\mathrm{PF}_{6}\right]$ as the supporting electrolyte [69] and Table 1 provides the $E_{1 / 2}$ data (measured vs. [ $\left.\mathrm{FeCp}{ }_{2}\right]$ ). For 11, a single oxidation wave is observed for the Fc redox centers, and the Fe ${ }^{I I I / I I}$ oxidation potential is found at $0.640 \mathrm{~V} v$ s. [FeCp* ${ }_{2}$ ] [69]. No adsorption phenomenon is observed in the CV for the ferrocenyl Janus compound 11 . The $\mathrm{Fe}^{\prime \prime \prime} / \mathrm{Fe}^{\prime \prime}$ curve of $\mathbf{1 1}$ is chemically $\left(i_{\mathrm{a}}=i_{\mathrm{c}}\right.$ ) and electrochemically reversible, although the value of $E_{\mathrm{pa}}-E_{\mathrm{pc}}(0.07 \mathrm{~V})$ is a slightly larger than the known value of $0.059 \mathrm{~V}$ for a fast redox process in term of an individual Fc moiety at $25^{\circ} \mathrm{C}[69,71,72]$. It could be due to the slight electrostatic factor between the two Fc groups, a known phenomenon $[73,74]$.

The Bard-Anson electrochemical method $[66,69,75]$, a method suitable for redox-active Fc-containing polymers and dendrimers with relatively low molecular weight, is utilized to calculate the number of Fc units in 11. As shown in Table 1, the calculated value of Fc number ( $F C_{\text {experimental) }}$ for $\mathbf{1 1}$ is $\mathbf{2} \pm \mathbf{0 . 2}$ (see Table S1 in Supporting Information for details of the measurements), which is in good agreement with the theoretical number ( $\left.F c_{\text {theoretical }}\right)$ of 2 calculated by using the targeted structure shown in Scheme 1. In short, the electrochemical 
determinations fully demonstrate the expected molecular structure of the new Fc-containing Janus molecule 11.

Table 1. Redox potentials $\left(E_{1 / 2}\right)$, chemical $\left(i_{c} / i_{a}\right)$ and electrochemical $(\Delta E)$ reversibility for $\mathbf{1 1}$ and its Fc number determined by the Bard-Anson electrochemical formula.

\begin{tabular}{cccccc}
\hline Dendrimer & $E_{1 / 2}{ }^{\mathrm{a}}$ & $\Delta E$ & $i_{c} / i_{a}$ & $F c_{\text {theoretical }}{ }^{\mathrm{b}}$ & $F c_{\text {experimental }}{ }^{\mathrm{d}}$ \\
\hline $\mathbf{1 1}$ & 0.640 & 0.07 & 1 & 2 & $2 \pm 0.2$ \\
\hline${ }^{\mathrm{a}} E_{1 / 2}=\left(E_{p a}+E_{p c}\right) / 2 \mathrm{vs} .\left[\mathrm{FeCp}_{2}{ }^{*}\right] ;{ }^{\mathrm{b}} \Delta E=E_{p a}-E_{p c} ;{ }^{\mathrm{c}}$ expected Fc number of $\mathbf{1 1}$ from its targeted \\
molecular structure; ${ }^{\mathrm{d}} \mathrm{Fc}$ number measured by the Bard-Anson electrochemical formula.
\end{tabular}

\section{Redox Reversibility of the Bond with the Janus Substrate 11}

As previously described, the Fc group is transformed into the cationic hydrophilic $\mathrm{Fc}^{+}$cation and undergoes reversible redox transformations owing to chemical or electrochemical stimuli [44]. To further prove this point, the Janus compound $\mathbf{1 1}$ is chemically oxidized using $\mathrm{FeCl}_{3}$, and the obtained cationic $\mathrm{Fc}^{+}$-containing Janus molecule is then reduced back to $\mathbf{1 1}$ by ascorbic acid following a whole oxidation-reduction circle. The compound $\mathbf{1 1}$ in dry methanol is oxidized using two equivalents of $\mathrm{FeCl}_{3}$. In the process of slowly adding the $\mathrm{FeCl}_{3}$ solution, a color change is observed from original yellow to pale green for the solution mixture (Fig. 4), the latter being the typical color of the $\mathrm{Fc}^{+}$-containing compounds. As expected, the obtained mixture exhibits an absorption band at $630 \mathrm{~nm}$ attributed to the unique $\mathrm{Fc}^{+}$segment, and in the meantime no peak is observed at $435 \mathrm{~nm}$ corresponding to the Fc moiety in the UV-vis. spectrum $[16,75,76]$. These results further indicate successful oxidation of the Fc group in the Janus compound $\mathbf{1 1 .}$

The reduction of the green $\mathrm{Fc}^{+}$-containing Janus molecule is then carried out stoichiometrically using ascorbic acid as the reductant to yield the original compound $\mathbf{1 1}$. After dropwise addition of the ascorbic acid solution, an obvious color change is found from pale green to yellow (Fig. 4). An absorption peak is observed again at $435 \mathrm{~nm}$, and at the same time the peak at $630 \mathrm{~nm}$ disappears. This data proves the re-formation of the neutral Fc group. In addition, the slight weakening in absorption intensity at $435 \mathrm{~nm}$ is mainly taken into account by the decreased concentration of the recovered compound $\mathbf{1 1}$ owing to the addition of solvent employed to dissolve the oxidant and reductant.

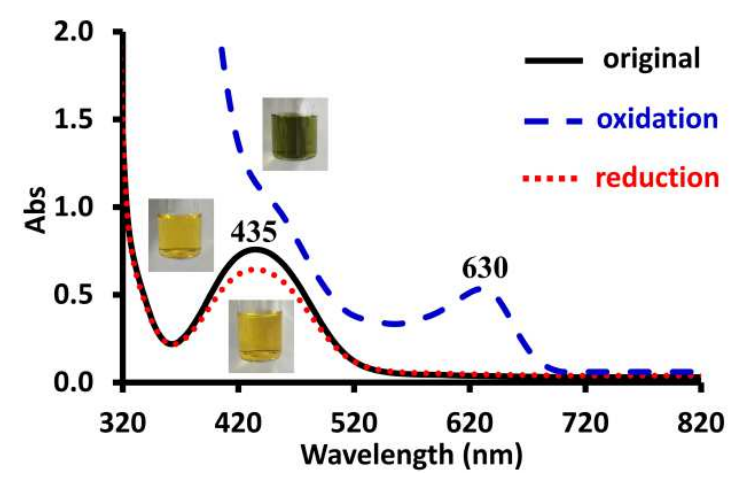

Fig. 4. UV-vis. spectral changes of $\mathbf{1 1}$ during an oxidation-reduction cycle. 


\section{Self-assembly of 11 in Water}

The Janus compound $\mathbf{1 1}$ contains three hydrophilic TEG branches and two hydrophobic Fc termini, and thus it is anticipated to self-assemble into micellar aggregates in aqueous solution. As shown in Fig. S17, the determined value of critical micelle concentration (CMC) for $\mathbf{1 1}$ is $0.447 \mathrm{mg} \mathrm{ml}^{-1}$ using the pyrene fluorescence probe technique $[68,77]$. In the light of this result, the concentration of $2.0 \mathrm{mg} \mathrm{ml}^{-1}$ were then employed to explore the self-assembly behavior of $\mathbf{1 1}$ in water.

The self-assembly process [76] is studied by slowly adding deionized water into the THF solution of 11, then the dialysis treatment is conducted to eliminate the residual THF solvent in the solution mixture. The yellow color of the dispersion suggests the formation of micelles, and the self-assembled nanostructures are studied by SEM, atomic force microscopy (AFM) and DLS. The SEM micrograph (Fig. 5a) shows evidence for a nearly spherical morphology of the micelles of 11, and the determined average diameter is $38 \pm 15 \mathrm{~nm}$ (Fig. 5b). Besides, the hydrodynamic diameter provided by DLS curve (Fig. $5 \mathrm{c}$ ) is $176 \mathrm{~nm}$ with a polydispersity index (PDI) of 0.096. As expected, DLS technique offers typically larger size of micelles than SEM method owing to their different determination circumstance. In the DLS measurement, the micelles in aqueous solution present the swelling and outstretched state, but SEM yields the size of micellar samples in the dry state $[16,68]$. Furthermore, the existence of size difference among the SEM and DLS measurements is best taken into account by some aggregation in the aqueous system. This phenomenon is also reflected by the AFM analysis. To prepare the sample for AFM analysis, several drops of micellar solution of $\mathbf{1 1}$ are casted onto a clean mica substrate. After being dried for $24 \mathrm{~h}$ in air, the sample is analyzed using the tapping mode. As shown in Fig. S19, the globular morphology of all the micelles is observed by AFM, and the average particle diameter ( $D_{a v}{ }^{A F M}$ ) of $370 \mathrm{~nm}$ is obtained according to the corresponding AFM-based statistical analysis. In short, these results indicate that $\mathbf{1 1}$ self assembles into micelles in water.

As described earlier, the Fc units of Janus molecule $\mathbf{1 1}$ are reversibly transformed between the oxidation and reduction state. Here, the effect on its self-assembly behavior are further studied using $\mathrm{FeCl}_{3}$ and ascorbic acid as oxidant and reductant, respectively. The redox-responsive experiments are conducted in aqueous system, and the morphologies and sizes of the micelles are monitored by SEM and DLS. Interestingly, for the aggregates $\mathbf{1 1}$ near-spherical micelles are still found by SEM (Fig. $5 \mathrm{~d}$ ), but the average size is improved to $104 \pm 20 \mathrm{~nm}$ (Fig. 5e). The hydrodynamic diameter distributions measured by DLS is about $278 \mathrm{~nm}$ with PDI $=0.423$ (Fig. 5f). Apparently, the increased average size and the broader scope of size distribution are attributed to the oxidation of the $\mathrm{Fc}$ groups to $\mathrm{Fc}^{+}$structures. This size increase is likely attributed to the electrostatic repulsion among the positively charged $\mathrm{Fc}^{+}$fragments. The reduction of the oxidized micelles is then conducted by adding ascorbic acid. As anticipated, the micellar size decreases after the addition of ascorbic acid. As shown in Fig. 5g, these re-formed micelles exhibit a spherical shape, and their average size by SEM is $52 \pm 15 \mathrm{~nm}$ (Fig. $5 \mathrm{~h}$ ), in good agreement with the initial size before oxidation treatment (Fig. 5a). Furthermore, DLS analysis also confirms this reversible change. As shown in Fig. 5i, the recovered micelles exhibit an average hydrodynamic diameter of $186 \mathrm{~nm}$ and narrow size distribution indicated by the low PDI of 0.109 . These data is consistent with the 
original value. In a word, according to the results of SEM and DLS, it is clear that the self-assembly process for $\mathbf{1 1}$ exhibits reversibility in aqueous solution.
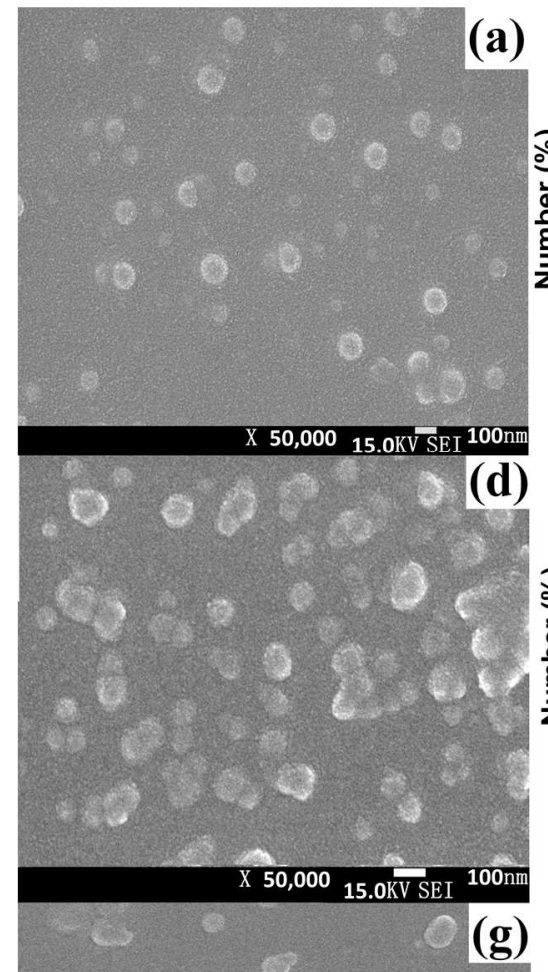

g)

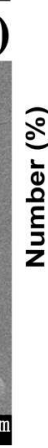

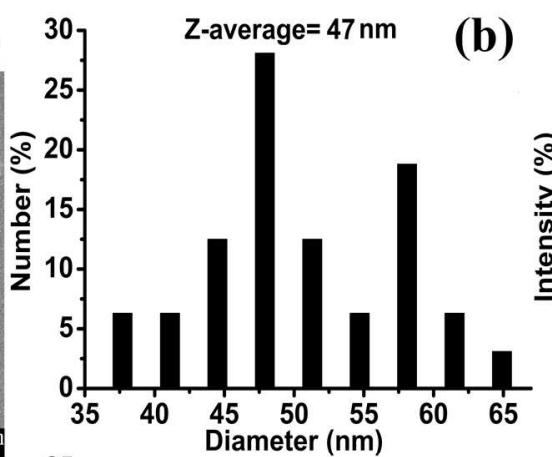

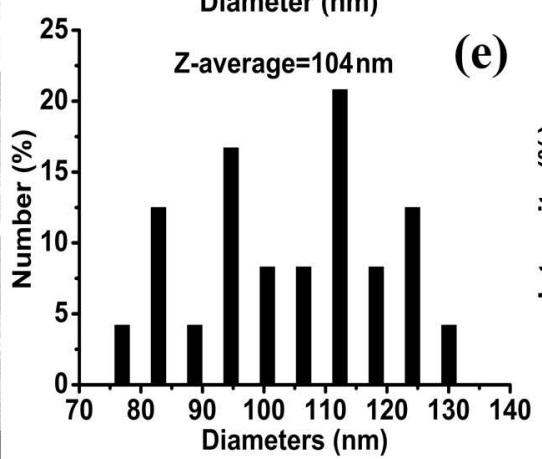

(e)
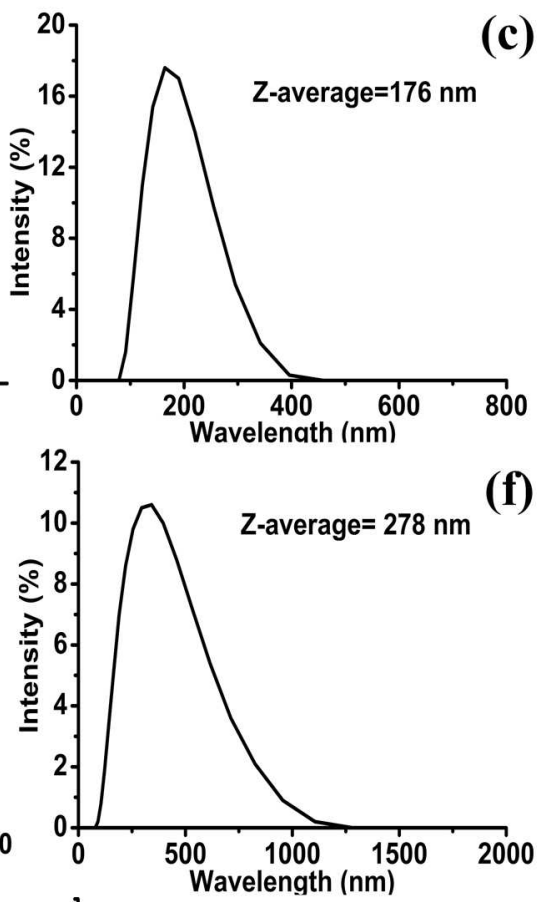

(h)

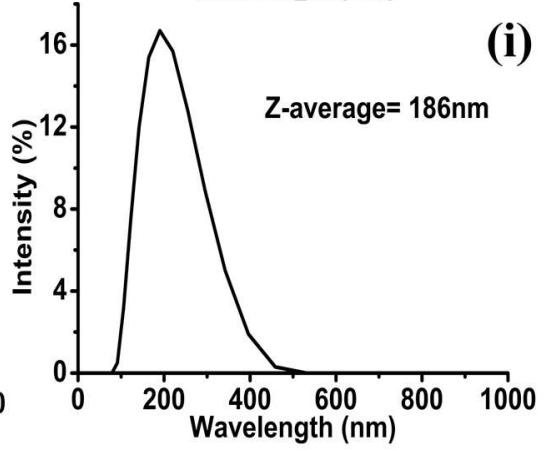

Fig. 5. SEM image (a) and statistical diameter distribution (b) of $\mathbf{1 1}$ micelles in water $(2.0 \mathrm{mg}$ $\mathrm{ml}^{-1}$ ), and their size distribution by DLS (c, PDI = 0.096). SEM image (d) and statistical diameter distribution (e) of the oxidized $\mathbf{1 1}$ micelles, and their size distribution by DLS ( $\mathrm{f}, \mathrm{PDI}$ = 0.423); SEM image (g) and statistical diameter distribution (h) of the reduced 11 micelles, and their size distribution by DLS (i, PDI = 0.109).

\section{Substrate loading and oxidation-controlled release from micelles of $\mathbf{1 1}$}

$\mathrm{RhB}$, a fluorescent molecule, is chosen as model drug to explore the encapsulating ability of micelles formed by Janus molecules $\mathbf{1 1}$. The substrate-encapsulated micelles are prepared by dropwise injecting deionized water into the mixed THF solution of $\mathbf{1 1}$ and RhB. After that, the obtained mixture are vigorously agitated at $r$. t. for $12 \mathrm{~h}$, followed by the dialysis treatment against distilled water to get rid of unencapsulated $\mathrm{RhB}$ molecules and remaining THF solvent. The successful encapsulation of RhB by micelles of $\mathbf{1 1}$ is demonstrated by the UV-vis. spectrum shown in Fig. S19a. As expected, a new peak attributed to the RhB molecules is observed at $563 \mathrm{~nm}$. The standard profile of RhB (Fig. S19b) is then applied to 
measure the amount of RhB loaded. The determined values are $0.04 \%$ for the loading content and $0.068 \%$ for the encapsulation efficiency, respectively.

As shown in Fig. 6a, micelles still exhibit the nearly spherical shape after the encapsulation of $\mathrm{RhB}$. The average diameter evidenced by SEM is $77 \pm 30 \mathrm{~nm}$ (Fig. 6b), and this value is a little larger than that of pure micelles (Fig. 5b). Moreover, a size of $217 \mathrm{~nm}$ is measured by using the DLS profile (Fig. 6c), and the corresponding PDI is 0.245 .
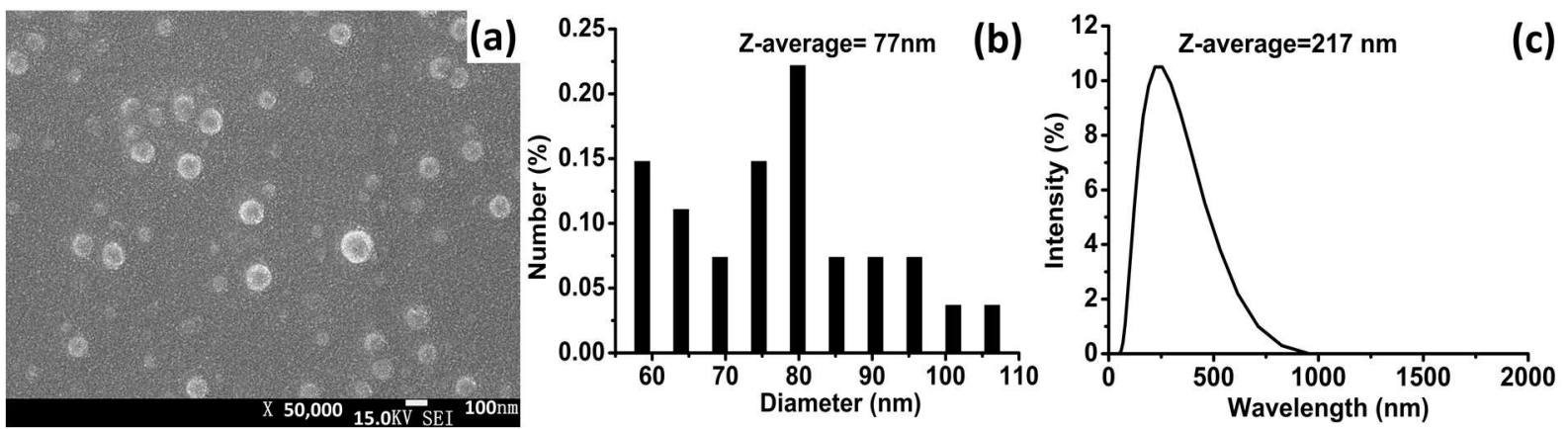

Fig. 6. RhB-loaded 11 micelles: (a) SEM image, (b) histogram of size distribution and (c) DLS curve $(\mathrm{PDI}=0.245)$.

The dialysis method was adopted to determine the in vitro release behavior of RhB from micelles of 11. Concretely, the RhB-loaded micellar solution is dialyzed against the aqueous solution of $\mathrm{FeCl}_{3}$ at $1.0 \mathrm{mg} \mathrm{ml}^{-1}$. At various intervals, a small amount of dialysate is taken out and analyzed using UV-vis. spectroscopy, and the released RhB is calculated using its standard curve $[68,76,77]$. Fig. 7 shows the release curve of RhB. As expected, the release of $\mathrm{RhB}$ from the micelles of $\mathbf{1 1}$ is trigged by the addition of $\mathrm{FeCl}_{3}$ at $1.0 \mathrm{mg} \mathrm{ml}^{-1}$. After $20 \mathrm{~h}$ of oxidation with $\mathrm{FeCl}_{3}$, the total amount released is $78 \%$ or so, and hereafter no further release is observed even after $28 \mathrm{~h}$. During the dialysis treatment by $\mathrm{FeCl}_{3}$, the $\mathrm{Fc}$ groups of Janus $\mathbf{1 1}$ are converted into cationic $\mathrm{Fc}^{+}$structures, and this transformation results in the improvement of coulombic repulsion in the cores of micelles [16]. Thus, the loaded RhB slip out from the enlarged cores of micelles.

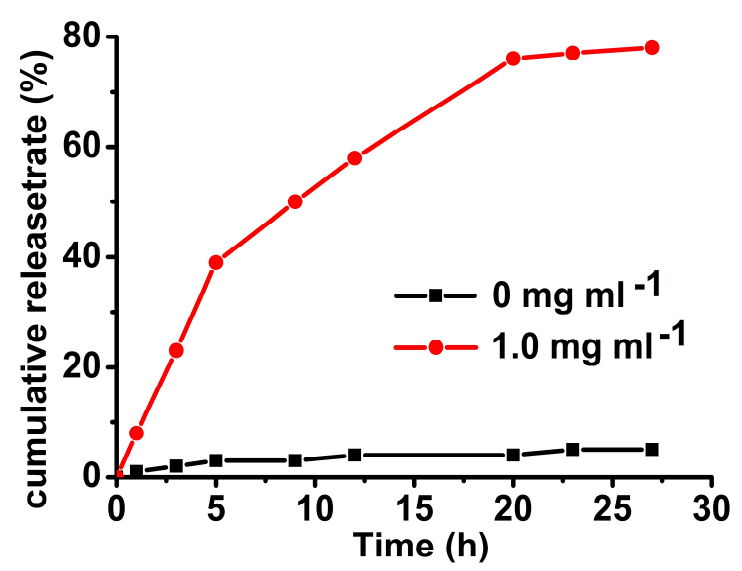

Fig. 7. In vitro release curve of $\mathrm{RhB}$ from the micelles of $\mathbf{1 1}$ using $\mathrm{FeCl}_{3}$ as oxidant at 0 and 1.0 $\mathrm{mg} \mathrm{ml}^{-1}$. 


\section{Formation of the Supramolecular Janus Compound $\beta-C D @ 11$}

It is well known that macrocyclic $\beta-C D$, as host molecule, has a specific structure with a hydrophilic exterior surface and hydrophobic interior cavity and thus accommodates hydrophobic small molecules such as adamantane, azobenzene and Fc via dynamic non-covalent host-guest interactions [40-42,44,76]. Based on this, herein, we further prepare the supramolecular Janus complex $\boldsymbol{\beta}-\mathrm{CD} @ \mathbf{1 1}$ using the compound $\mathbf{1 1}$ and $\beta-C D$ as the starting materials (Fig. 1). The formation of this supramolecular substrate is confirmed by the results of one- and two-dimensional ${ }^{1} \mathrm{H}$ NMR analysis. Fig. 8 provides the ${ }^{1} \mathrm{H} N M R$ spectra of 11, $\beta-C D$ and $\boldsymbol{\beta}-\mathbf{C D} @ 11$, and their comparison indicates the host-guest interaction between $\beta-C D$ and Fc units in 11. As expected, several obvious shift changes are found for the characteristic peaks of $\beta-C D$ and Fc moieties (Table 2). The peaks at 3.623 and 3.604 ppm are attributed to $\mathrm{H}-3$ and $\mathrm{H}-5$ protons of the $\beta-\mathrm{CD}$ hydrophobic cavity. After mixing $\beta-\mathrm{CD}$ with 11, the two peaks are found at 3.653 and 3.634 ppm, respectively. Namely, the complexation-induced shift change $(\Delta \delta)$ is $0.030 \mathrm{ppm}$ for both cases. These changes are taken into account by the anisotropic shielding effect $[31,78]$. For the peaks of the $\mathrm{Cp}$ protons in Fc groups, similar shift changes are observed. The corresponding peaks are shifted from $4.328,4.175$ and $4.165 \mathrm{ppm}$ to $4.341,4.197$ and $4.176 \mathrm{ppm}$, respectively, and the $\Delta \delta$ values are $0.013,0.022$ and $0.011 \mathrm{ppm}$. These changes indicate that the complexation between $\beta-C D$ and the Fc units in 11 is successfully achieved.
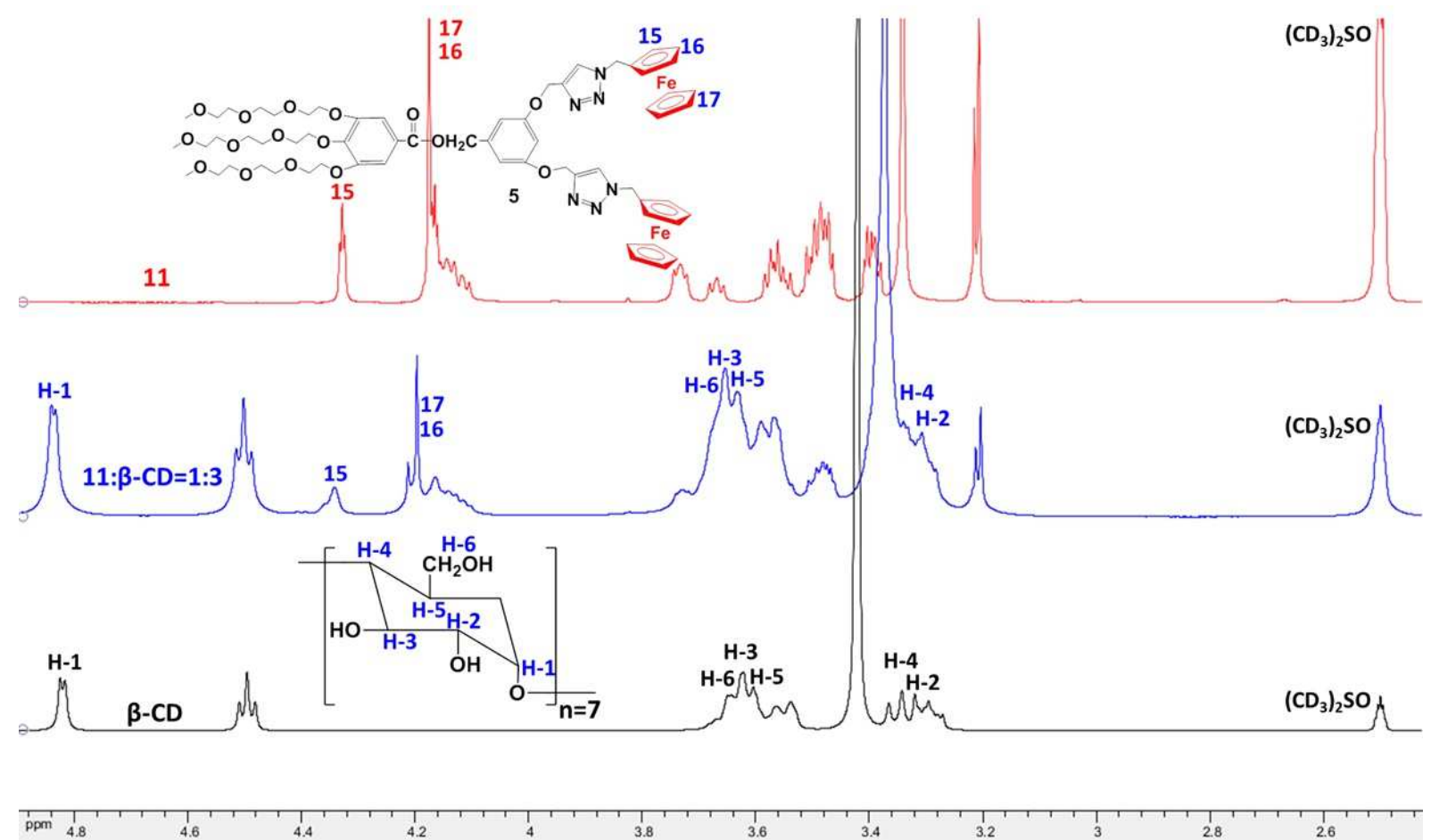

Fig. 8. ${ }^{1} \mathrm{H}$ NMR spectra in DMSO- $d_{6}$ of $11, \beta-C D$ and $\beta-C D @ 11$. 
Table 2. Chemical shifts of $\beta-C D$ and Fc groups before and after complexation (ppm).

\begin{tabular}{lccccc}
\hline Proton & $\mathrm{H}-3$ & $\mathrm{H}-5$ & 15 & 16 & 17 \\
\hline $\mathbf{1 1}$ & - & - & 4.328 & 4.175 & 4.165 \\
$\beta-C D$ & 3.623 & 3.604 & - & - & - \\
$\beta-C D @ 11$ & 3.653 & 3.634 & 4.341 & 4.197 & 4.176 \\
$\Delta \delta$ & 0.030 & 0.030 & 0.013 & 0.022 & 0.011 \\
\hline
\end{tabular}

Nevertheless, for purpose of further confirmation of the well-off construction of $\boldsymbol{\beta}$-CD@11 by supramolecular complexation, 2D-NOESY is chosen for the research of the complex formation. Protons with close proximity in two dimensions exhibit enhanced nuclear Overhauser effect (NOE) [31], which typically occurs at distances of $4 \AA$ and lower $[31,75,76]$. As for the inclusion complexes, the peaks of the host and guest protons are usually found extremely close to present correlation through the $\operatorname{NOE}[31,78,79]$. As shown in Fig. 9, the cross-peaking, protruded by using black squares, are found at the intersection of 3.32-3.67 and 4.10-4.35 ppm, which is attributed to the close adjoining of the Fc moieties and the $\mathrm{H} 3$ and $\mathrm{H} 5$ protons in the cavities of $\beta-C D$, respectively. The appearance of these cross-peaking confirms the successful formation of the inclusion complex $\beta-C D @ 11$.

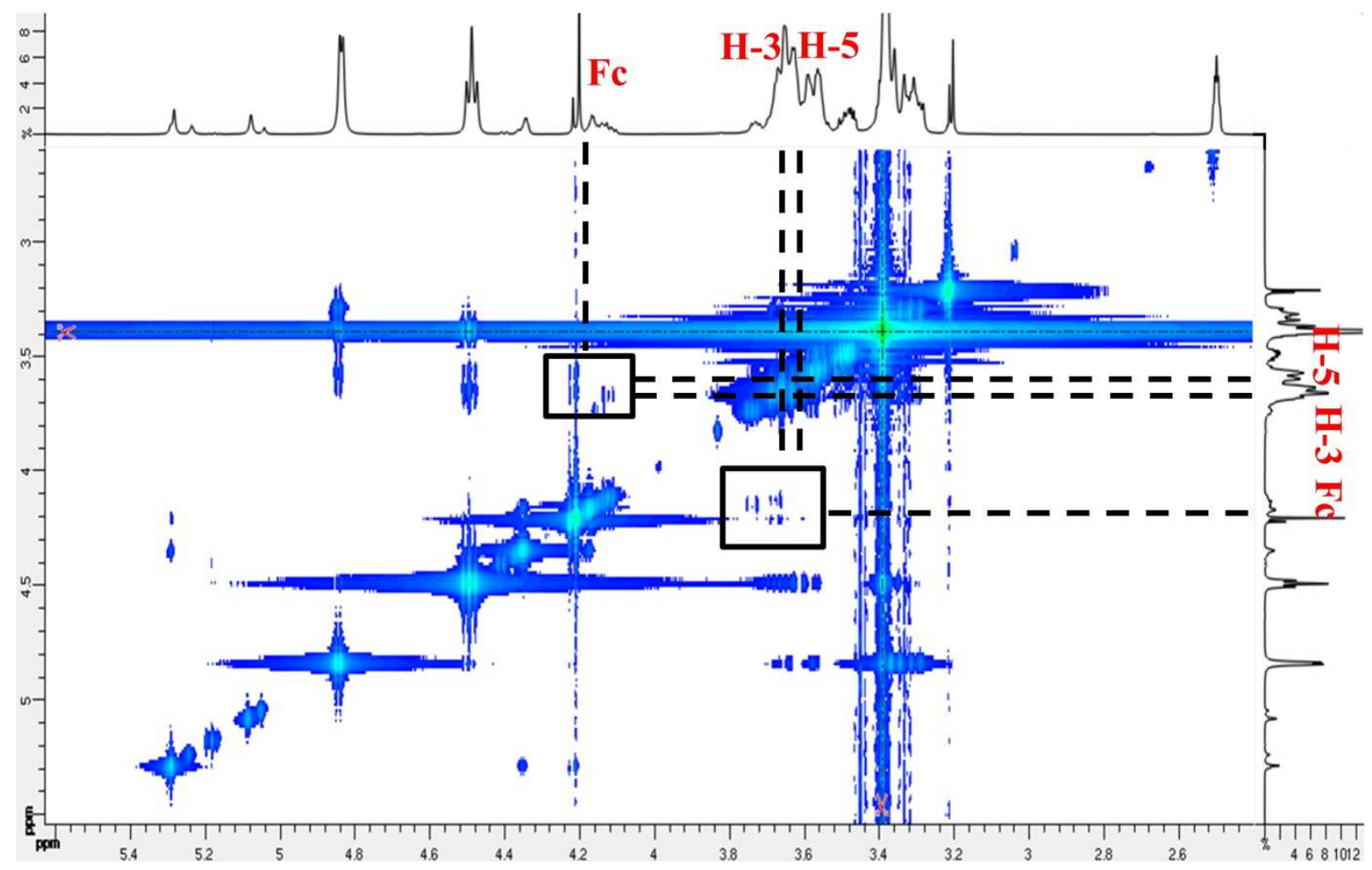

Fig. 9. 2D NOESY NMR spectrum of $\beta-C D @ 11$ in DMSO- $d_{6}$.

\section{Redox-Reversible Self-assembly of $\beta-C D @ 11$ in Aqueous Solution}

The pyrene fluorescence probe technique $[68,77]$ is also employed to determine the CMC value of the supramolecular Janus ensemble $\boldsymbol{\beta}-\mathrm{CD} @ 11$, and the calculated value is $0.661 \mathrm{mg}$ $\mathrm{ml}^{-1}$ (Fig. S21). The resulting CMC of $\boldsymbol{\beta}-\mathrm{CD} @ 11$ is higher than that of Janus $\mathbf{1 1}$ as a result of its better hydrophilcity than the original Janus molecule $11[68,77]$. On this basis, the 
concentration of $4.0 \mathrm{mg} \mathrm{ml}^{-1}$, above the CMC of $\boldsymbol{\beta}-\mathrm{CD} @ 11$, is chosen to investigate its self-assembly behavior.

Like the case of micelles of 11, the micelles of $\boldsymbol{\beta}-\mathbf{C D} @ 11$ are fabricated using the dialysis method. Concretely, the $\beta-C D @ 11$ micelles are prepared by slowly injecting deionized water into the DMSO solution of $\boldsymbol{\beta}-\mathbf{C D} @ 11$. After that, the obtained mixture is vigorously agitated at $30{ }^{\circ} \mathrm{C}$ for $24 \mathrm{~h}$, then the excess DMSO solvent is eliminated by the $72 \mathrm{~h}$ dialysis against distilled water. The morphology and size of the obtained micelles are well characterized by SEM and DLS. The spherical morphology of $\beta$-CD@11 micelles is confirmed by the SEM image (Fig. 10a), and the corresponding statistic analysis provides an average diameter of $75 \pm 20$ $\mathrm{nm}$ or so (Fig. 10b). As expected, this value is obviously smaller than the size of $450 \mathrm{~nm}$ obtained by DLS curve (Fig. 10c), which is attributed to their different testing conditions. The size of $\beta-C D @ 11$ micelles is moderately larger than that of the corresponding pure micelles of 11 , which is taken into account by the bulky inclusion complex of $\beta-C D$ with Fc units.
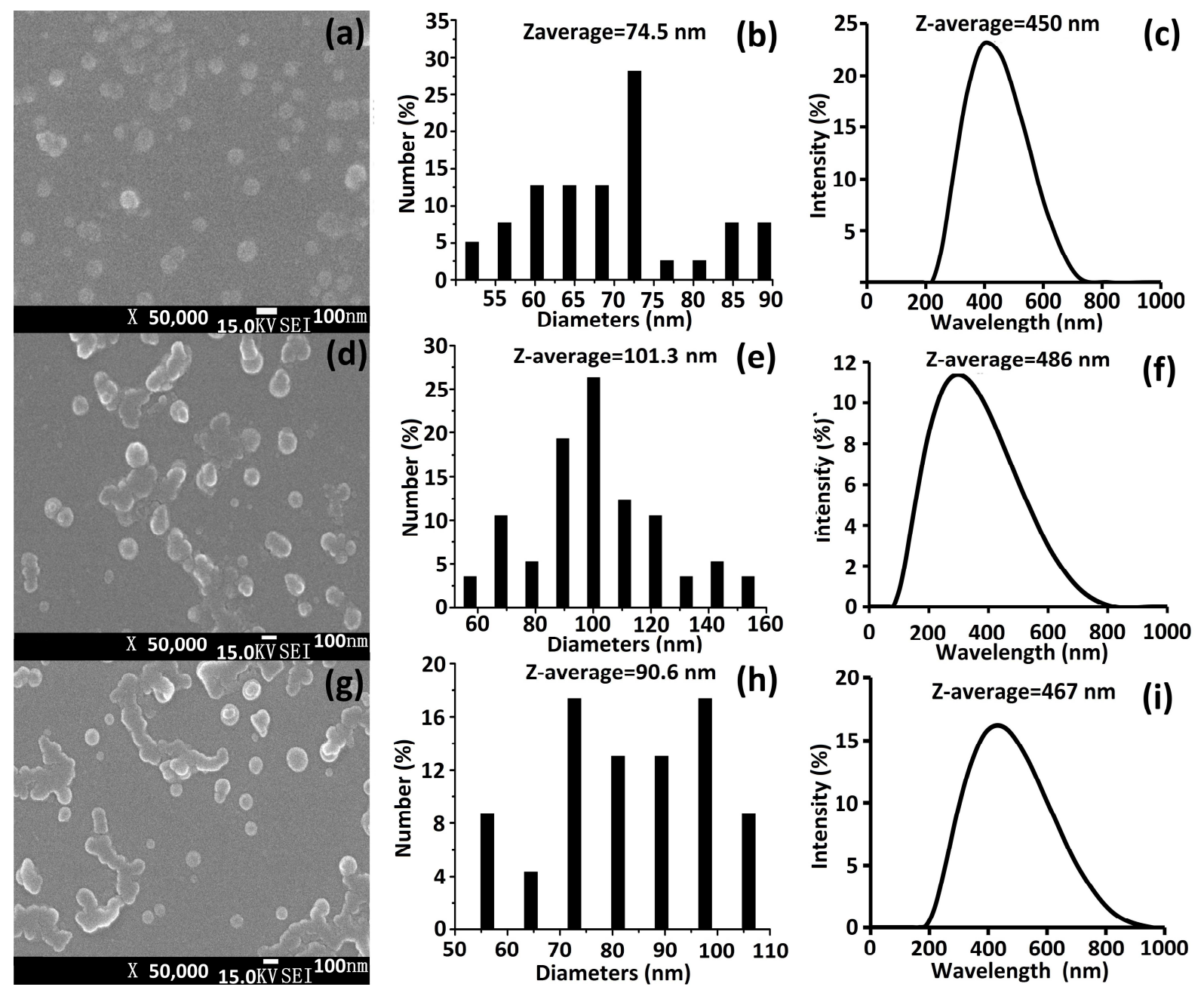

Fig. 10. SEM image (a) and statistical diameter distribution (b) of $\beta-C D @ 11$ micelles and their size distribution by DLS (c). SEM image (d) and statistical diameter distribution (e) of the oxidized $\beta$-CD@11 micelles and their size distribution by DLS (f); SEM image (g) and statistical diameter distribution ( $h$ ) of the reduced $\beta-C D @ 11$ micelles and their size distribution by DLS (i). 
Because of the presence of Fc groups, the amphiphilic supramolecular Janus ensemble $\boldsymbol{\beta}$-CD@11 should be redox switchable. Thus, it is interesting to probe the redox-responsive self-assembly behavior of $\boldsymbol{\beta}-\mathbf{C D} @ 11$ through chemical methods. Herein, $\mathrm{FeCl}_{3}$ and ascorbic acid are used as oxidizing and reducing agents, respectively, to carry out the redox reactions [80], and the change of micelles during this process is detected using SEM and DLS techniques. The aggregates $\boldsymbol{\beta}-\mathbf{C D} @ 11$ in the oxidation state still keep the near-spherical morphology, which is evidenced by the SEM image in Fig. 10d. The corresponding statistical analysis yields an average diameter of $101 \pm 40 \mathrm{~nm}$ or so (Fig. 10e). The hydrodynamic diameter distributions determined by DLS is about $486 \mathrm{~nm}$ with PDI $=0.640$ (Fig. 10f). Compared to the micelles in original state, these oxidized micelles exhibit an increased size. Apparently, this increase is attributed to the oxidation of $\mathrm{Fc}$ into $\mathrm{Fc}^{+}$. Conceivably, along the oxidation process, the dissociation of the inclusion complexes ( $\beta-C D$ : $F c=1: 1$ ) occurs, and the strong electrostatic repulsion among the $\mathrm{Fc}^{+}$fragments further leads to swelling of the micelles (Fig. 1).

The micelles solution are then reduced by injecting ascorbic acid to test the reversibility of this change. As anticipated, the addition of ascorbic acid results in size decrease of the obtained micelles. As shown in Fig. 10g, the spherical silhouette is still observed for these re-formed micelles, and the average size is reduced to $90 \pm 30 \mathrm{~nm}$ (Fig. 10h). There is a slight size distinction between the reduced micelles and the original ones before oxidation treatment (Fig. 10a) that is attributable to the presence of residual oxidized micelles. Perhaps, prolonged equilibration treatment leads to inclusion complex re-formation. Therefore, it may be that this process is not perfectly reversible. Furthermore, DLS analysis also indicates the recovery. As shown in Fig. 10i, these recovered micelles exhibit an average hydrodynamic diameter of $467 \mathrm{~nm}$ (PDI = 0.603), and this value is almost equal to the original value before oxidation. In short, both SEM and DLS measurements confirm the reversible self-assembly behavior of the supramolecular Janus ensemble $\boldsymbol{\beta}-\mathbf{C D} @ 11$ in water, and this change is successfully fulfilled by redox reactions.

\section{Substrate-Loading and Oxidation-triggered Release from Micelles of $\beta$-CD@11}

As a model fluorescent molecule, RhB is further employed to study the substrate-loading property of the micelles formed by the supramolecular Janus ensemble $\boldsymbol{\beta}-\mathbf{C D} @ 11$. The RhB-loaded micelles of $\boldsymbol{\beta}-\mathbf{C D} @ 11$ are prepared by injecting slowly deionized water into the DMSO solution of $\beta-C D @ 11$ and RhB, then the obtained mixture is vigorously agitated at $r$. $t$. for $12 \mathrm{~h}$. The dialysis treatment is then carried out against deionized water to get rid of the remaining DMSO solvent and excess RhB molecules. The successful formation of RhB-loaded micelles of $\boldsymbol{\beta}$-CD@11 is confirmed by UV-vis. spectroscopy. As shown in Fig. S23, the appearance of the characteristic absorption peak at $560 \mathrm{~nm}$ indicates the existence of RhB in the obtained micelles. The amount of loaded-RhB is then determined using the standard profile of RhB (Fig. S18b). The obtained values are $1.38 \%$ for the loading content and $1.8 \%$ for the encapsulation efficiency, respectively. These values are much larger than those obtained for micelles of $\mathbf{1 1}$, indicating the better cargo-loading property of the supramolecular micelles of $\boldsymbol{\beta}-\mathrm{CD} @ 11$.

The SEM micrograph (Fig. 11a) shows the nearly spherical shape of RhB-encapsulated micelles of $\boldsymbol{\beta}-\mathbf{C D} @ 11$, and the corresponding statistical analysis provides the average 
diameter of $110 \pm 20 \mathrm{~nm}$ (Fig. 11b), which is a little larger than that of empty pure micelles (Fig. 10a). As shown in Fig. 11c, the average hydrodynamic diameter of $500 \mathrm{~nm}$ is observed through the DLS analysis, and the corresponding PDI is only 0.143 , indicating that these micelles in aqueous system have very narrow size distribution.

The dialysis method is adopted to determine the in vitro release behavior of RhB-containing micelles of $\beta-C D @ 11$. Concretely, the RhB-loaded micelle $\beta-C D @ 11$ is dialyzed against the aqueous solution of $\mathrm{FeCl}_{3}$ at $1.0 \mathrm{mg} \mathrm{ml}^{-1}$. At various intervals, a small amount of dialysate is taken out and analyzed using UV-vis. spectroscopy, and the amount of released RhB is determined using its standard curve $[68,76,77]$. As shown in Fig. 12, the release of RhB from micelles of $\beta-C D @ 11$ is initiated by treatment with $\mathrm{FeCl}_{3}$ at $1.0 \mathrm{mg} \mathrm{ml}^{-1}$. The total release amount of $\mathrm{RhB}$ reaches $55 \%$ after $25 \mathrm{~h}$ of dialysis treatment with $\mathrm{FeCl}_{3}$, and hereafter no further release is observed even after $55 \mathrm{~h}$. During the dialysis treatment by $\mathrm{FeCl}_{3}$, the $\mathrm{Fc}$ groups of Janus $\mathbf{1 1}$ are oxidized to cationic $\mathrm{Fc}^{+}$structures, and this transformation results in the weakening of the binding between $\beta-C D$ and 11 . Thereby, their inclusion complexes are disintegrated and the micelle expanded due to the enhancement of the coulombic repulsion force in the cores [16]. Thus, the loaded RhB runs away from the enlarged cores of micelles. Based on the above release feature, this supramolecular micellar ensemble is anticipated to have potential applications in the fields of sustained drug delivery systems $[44,81]$.
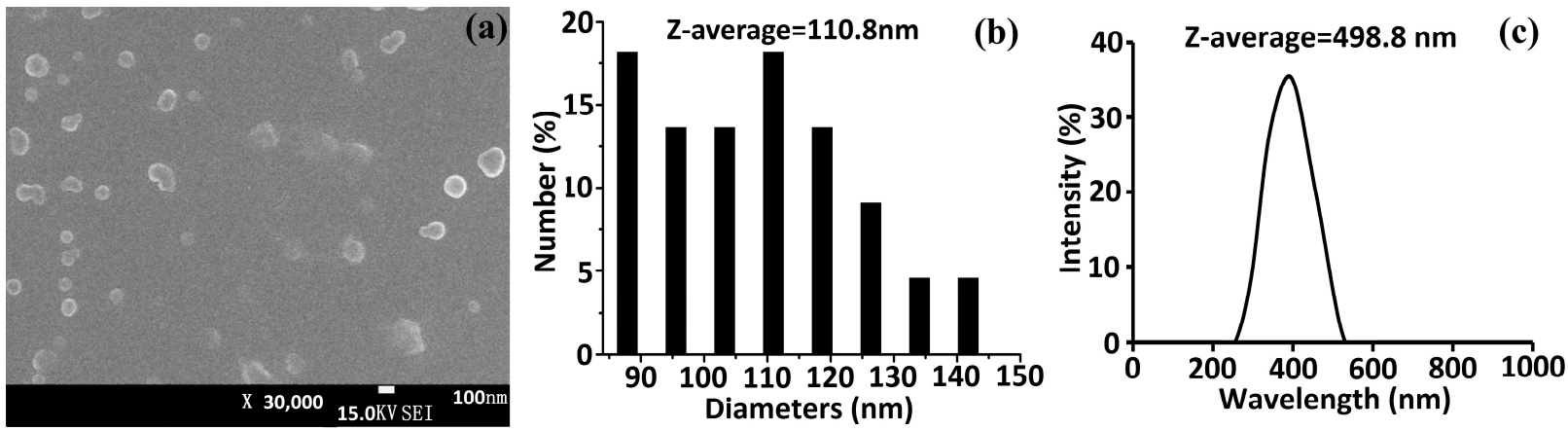

Fig. 11. RhB-loaded micelles $\beta$-CD@11: (a) SEM image, (b) histogram of size distribution and (c) DLS curve.

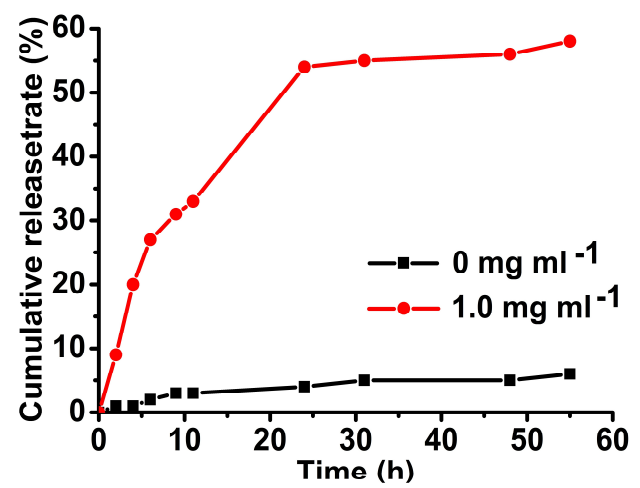

Fig. 12. In vitro release profile of $\mathrm{RhB}$ from micelles $\beta-\mathrm{CD} @ 11$ using $\mathrm{FeCl}_{3}$ as oxidant at 0 and $1.0 \mathrm{mg} \mathrm{ml}^{-1}$. 


\section{CONCLUSION}

The design and facile synthesis of a new supramolecular Janus system with a redox response based on the inclusion complexation of $F c$ groups into $\beta$ - $C D$ is reported here. A typical chemo selective coupling method is successfully used for the efficient synthesis of a new bis-Fc-terminated Janus molecule containing three hydrophilic triethylene glycol branches. The new bimetallic Janus molecule is then employed as a building block to fabricate a supramolecular Janus device through the strong host-guest interaction between $\mathrm{Fc}$ group and $\beta-C D$ at 1:1 molar ratio. The successful fabrication of this supramolecular device is confirmed using one-dimensional ${ }^{1} \mathrm{H}$ NMR and two-dimensional nuclear Overhauser enhancement spectroscopy. The supramolecular Janus ensemble self-assembles into nearly spherical micelles on nanoscale in the aqueous system. The reversible expansion and contraction of these supramolecular micelles, as indicated by SEM and DLS, are initiated by the oxidation and reduction of $\mathrm{Fc}$ moieties that control the host-guest interaction of $\mathrm{Fc}$ with $\beta$-CD. The redox-responsive supramolecular Janus system is successfully applied to the encapsulation of model RhB cargo, and the loaded molecules slips out from the micelles upon adding the oxidant $\mathrm{FeCl}_{3}$. This work provides a good example of rational design of supramolecular Janus molecules by host-guest inclusion between $\beta-C D$ and $F c$ groups, and the present supramolecular micelles have the potential of inducing progress in the field of redox-responsive cargo delivery systems.

$\begin{array}{ll}\text { Abbreviations } & \\ \beta-C D & \beta \text {-cyclodextrin } \\ \text { Fc } & \text { ferrocene } \\ \text { PDMA } & \text { poly(N,N-dimethylacrylamide) } \\ \text { PDEA } & \text { poly(N,N-diethylacrylamide) } \\ \text { PAMAM } & \text { poly(amidoamine) } \\ \text { Ad } & \text { adamantane } \\ \text { Fc } & \text { ferricinium } \\ \text { ROS } & \text { reactive oxygen species } \\ \text { GSH } & \text { glutathione } \\ \text { TEG } & \text { triethylene glycol } \\ \text { NOSEY } & \text { Nuclear Overhauser Enhancement Spectroscopy } \\ \text { SEM } & \text { scanning electron microscopy } \\ \text { DLS } & \text { dynamic light scattering } \\ \text { RhB } & \text { Rhodamine B } \\ \text { MWCO } & \text { molecular weight cutoff } \\ \text { LC } & \text { loading content } \\ \text { EE } & \text { encapsulation efficiency } \\ \text { CUAAC } & \text { copper(I)-catalyzed azide alkyne cycloaddition } \\ \text { Cp } & \text { cyclopentadienyl } \\ \text { DMSO } & \text { dimethyl sulfoxide } \\ \text { CMC } & \text { critical micelle concentration } \\ \text { PDI } & \text { polydispersity index } \\ & \\ & \end{array}$




\section{Acknowledgements}

We thank Ms. Wang Zhonghui (College of Light Industry, Textile and Food Engineering, Sichuan University) for her great help in AFM and DLS measurements and the ceshigo (www.ceshigo.com) for help in SEM. The financial support from the Science \& Technology Department of Sichuan Province (No. 2018HH0038), the University of Bordeaux and the Centre National de la Recherche Scientifique (CNRS) are gratefully acknowledged.

\section{Corresponding Authors}

guhaibinkong@126.com; didier.astruc@u-bordeaux.fr

\section{Notes}

The authors declare no competing financial interest.

\section{Appendix A. Supplementary data}

The electronic supplementary information contains the syntheses, spectra, calculation of the number of Fc units in the dendrimer $\mathbf{1 1}$ and references (PDF). Supplementary data to this article can be found online at https://

\section{REFERENCES}

[1] H.J. Sun, S. Zhang, V. Percec, Chem. Soc. Rev. 44 (2015) 3900-3923.

[2] K.R. Raghupathi, J. Guo, O. Munkhbat, P. Rangadurai, S. Thayumanavan, Acc. Chem. Res. 47 (2014) 2200-2211.

[3] A.-M. Caminade, R. Laurent, B. Delavaux-Nicot, J.-P. Majoral, New J. Chem. 36 (2012) 217-226.

[4] D.R. Sikwal, R.S. Kalhapure, T. Govender, Eur. J. Pharm. Sci. 97 (2017) 113-134.

[5] V. Percec, M.R. Imam, M. Peterca, P. Leowanawat, J. Am. Chem. Soc. 134 (2012) 44084420.

[6] J.W. Choi, B.K. Cho, Soft. Matter 7 (2011) 4045-4049.

[7] J. Liu, Y. Feng, Y. He, N. Yang, Q.H. Fan, New. J. Chem. 36 (2012) 380-385.

[8] T. Tuuttila, J. Lipsonen, M. Lahtinen, J. Huuskonen, K. Rissanen, Tetrahedron 64 (2008) 10590-10597.

[9] M. Filippi, D. Patrucco, J. Martinelli, M. Botta, P. Castro-Hartmann, L. Tei, E. Terreno, Nanoscale 7 (2015) 12943-12954.

[10] C. Dengiz, B. Breiten, J.P. Gisselbrecht, C. Boudon, N. Trapp, W.B. Schweizer, F. Diederich, J. Org. Chem. 80 (2015) 882-896.

[11] R.L. Tang, S.M. Zhou, Z.Y. Cheng, G. Yu, Q. Peng, H.H. Zeng, G.C. Guo, Q.Q. Li, Z. Li, Chem. Sci. 8 (2017) 340-347.

[12] M. Peterca, V. Percec, P. Leowanawat, A. Bertin, J. Am. Chem. Soc. 133 (2011) 20507- 
20520.

[13] Q. Xiao, S.E. Sherman, S.E. Wilner, X. Zhou, C. Dazen, T. Baumgart, E.H. Reed, D.A. Hammer, W. Shinoda, M. Klein, V. Percec, Proc. Natl. Acad. Sci. U. S. A. 114 (2017) E7045-E7053.

[14] S. Nummelin, M. Selin, S. Legrand, J. Ropponen, J. Seitsonen, A. Nykänen, J. Koivisto, J. Hirvonen, M.A. Kostiainen, L.M. Bimbo, Nanoscale 9 (2017) 7189-7198.

[15] A. Lancelot, R. Clavería-Gimeno, A. Velázquez-Campoy, O. Abian, J.L. Serrano, T. Sierra, Eur. Polym. J. 90 (2017) 136-149.

[16] L. Zhao, Q.J. Ling, X. Liu, C.D. Hang, Q.X. Zhao, F.F. Liu, H.B. Gu, Appl. Organomet. Chem. 32 (2018) e4000.

[17] C. Ornelas, J. Ruiz, E. Cloutet, S. Alves, D. Astruc, Angew. Chem.-Int. Edit. 46 (2007) 872877.

[18] G.-R. David, P.H.J.S. Albertus, Chem. Mat. 23 (2011) 310-325.

[19] X.D. Chi, G.C. Yu, L. Shao, J.Z. Chen, F.H. Huang, J. Am. Chem. Soc. 138 (2016) 3168-3174.

[20] M.M. Zhang, X.Z. Yan, F.H. Huang, Z.B. Niu, H.W. Gibson, Acc. Chem. Res. 47 (2014) 1995-2005.

[21] S.Y. Dong, B. Zheng, F. Wang, F.H. Huang, Acc. Chem. Res. 47 (2014) 1982-1994.

[22] Z. Hou, W. Dehaen, J. Lyskawa, P. Woisel, R. Hoogenboom, Chem. Commun. 53 (2017) 8423-8426.

[23] Z.F. Sun, F.C. Lv, L.J. Cao, L. Liu, Y. Zhang, Z.G. Lu, Angew. Chem.-Int. Edit. 54 (2015) 79447948.

[24] M. Haring, D.D. Diaz, Chem. Commun. 52 (2016) 13068-13081.

[25] A. Harada, S. Takahashi, J. Chem. Soc. Chem. Commun. 10 (1984) 645-646.

[26] A. Ueno, F. Moriwali, T. Matsue, T. Osa, F. Hamada, K. Murai, Makromol. Chem. Rapid Commun. 6 (1985) 231-233.

[27] T. Matsue, D.H. Evans, T. Osa, N. Kobayashi, J. Am. Chem. Soc. 107 (1985) 3411-3417.

[28] A.E. Kaifer, Acc. Chem. Res. 32 (1999) 62-71.

[29] A. Harada, Acc. Chem. Res. 34 (2001) 456-464.

[30] M. Nakahata, Y. Takashima, H. Yamaguchi, A. Harada, Nat. Commun. 511 (2011).

[31] B.V.K.J. Schmidt, D. Kugele, J. von Irmer, J. Steinkoenig, H. Mutlu, C. Rüttiger, C.J. Hawker, M. Gallei, C. Barner-Kowollik, Macromolecules 50 (2017) 2375-2386.

[32] F. Chen, L.D. Kong, L. Wang, Y. Fan, M.W. Shen, X.Y. Shi, J. Mater. Chem. B 5 (2017) 84598466.

[33] G.Y. Li, Z.R. Dong, Y.T. Zhu, W.J. Tong, C.Y. Gao, J. Colloid Interface Sci. 475 (2016) 196202.

[34] E. Wajs, T.T. Nielsen, K.L. Larsen, A. Fragoso, Nano Res. 9 (2016) 2070-2078.

[35] Q. Yan, J.Y. Yuan, Z.N. Cai, Y. Xin, Y. Kang, Y.W. Yin, J. Am. Chem. Soc. 132 (2010) 92689270.

[36] Y. Kang, Y. Ma, S. Zhang, L.S. Ding, B.J. Li, ACS Macro Lett. 4 (2015) 543-547.

[37] C. Zuo, X.Y. Dai, S.J. Zhao, X.N. Liu, S.L. Ding, L.W. Ma, M.Z. Liu, H. Wei, ACS Macro Lett. 5 (2016) 873-878.

[38] Y. Wang, H.B. Wang, Y.J. Chen, X.S. Liu, Q. Jin, J. Ji, Colloid Surf. B-Biointerfaces 121 (2014)189-195.

[39] Y. Zhang, J.K. Duan, L.G. Cai, D. Ma, W. Xue, ACS Appl. Mater. Interfaces 8 (2016) 29343- 
29355.

[40] X.J. Loh, Mater. Horiz. 1 (2014) 185-195.

[41] Q.D. Hu, G.P. Tang, P.K. Chu, Acc. Chem. Res. 47 (2014) 2017-2025.

[42] B.V.K.J. Schmidt, M. Hetzer, H. Ritter, C. Barner-Kowollik, Prog. Polym. Sci. 39 (2014) 235249.

[43] L. Peng, A.C. Feng, M. Huo, J.Y. Yuan, Chem. Commun. 50 (2014) 13005-13014.

[44] H.B. Gu, S.D. Mu, G.R. Qiu, X. Liu, L. Zhang, Y.F. Yuan, D. Astruc, Coord. Chem. Rev. 364 (2018) 51-85.

[45] L. Peng, S.Y. Liu, A.C. Feng, J.Y. Yuan, Mol. Pharmaceutics 14 (2017) 2475-2486.

[46] F. Szillat, B.V.K.J. Schmidt, A. Hubert, C. Barner-Kowollik, H. Ritter, Macromol. Rapid Commun. 35 (2014) 1293-1300.

[47] F. Li, T. Ito, J. Am. Chem. Soc. 135 (2013) 16260-16263.

[48] T. Gao, L.D. Li, B. Wang, J. Zhi, Y. Xiang, G.X. Li, Anal. Chem. 88 (2016) 9996-10001.

[49] M. Gade, A. Paul, C. Alex, D. Choudhury, H.V. Thulasiram, R. Kikkeri, Chem. Commun. 51 (2015) 6346-6349.

[50] L. Peng, A.C. Feng, S.Y. Liu, M. Huo, T. Fang, K. Wang, Y. Wei, X.S. Wang, J.Y. Yuan, ACS Appl. Mater. Interfaces 8 (2016) 29203-29207.

[51] G. Xu, D. Pranantyo, L.Q. Xu, K.G. Neoh, E.-T. Kang, S.L.-M. Teo, Ind. Eng. Chem. Res. 55 (2016) $10906-10915$.

[52] F. Wang, H.T. Pu, X. Che, Chem. Commun. 52 (2016) 3516-3519.

[53] K. Miyamae, M. Nakahata, Y. Takashima, A. Harada, Angew. Chem.-Int. Edit. 54 (2015) 8984-8987.

[54] Y. Kang, X. Ju, L.S. Ding, S. Zhang, B.J. Li, ACS Appl. Mater. Interfaces. 9 (2017) 44754484.

[55] S. Nlate, J. Ruiz, J.-C. Blais, D. Astruc, Chem. Commun. (2000) 417-418.

[56] G.R. Newkome, C.D. Shreiner, Chem. Rev. 110 (2010) 6338-6442.

[57] D. Astruc, E. Boisselier, C. Ornelas, Chem. Rev. 110 (2010) 1857-1959.

[58] C.M. Casado, B. Alonso, J. Losada, M.P. Garcia-Armada, in Designing Dendrimers, S. Campana, P. Ceroni, F. Puntoriero, Eds., Wiley, Hoboken, NJ, 2012, pp. 219-262.

[59] D. Astruc, Nat. Chem. 4 (2012) 255-267.

[60] D. Astruc, Eur. J. Inorg. Chem. (2017) 6-29.

[61] Y.R. Leroux, H. Fei, J.M. Noël, P. Hapiot, J. Am. Chem. Soc. 132 (2010) 14039-14041.

[62] X. Liu, S.D. Mu, G.R. Qiu, Y.R. Long, Q.J. Ling, J.J. He, H.B. Gu, Polymer 146 (2018) 275290.

[63] J. Ruiz, D. Astruc, C.R. Acad. Sci. Sér. Ilc 1 (1998) 21-27.

[64] I. Noviandri, K.N. Brown, D.S. Fleming, P.T. Gulyas, P.A. Lay, A.F. Masters, L. Phillips, J. Phys. Chem. B. 103 (1999) 6713-6722.

[65] J. Ruiz, M.-C. Daniel, D. Astruc, Can. J. Chem. 84 (2006) 288-299.

[66] J.B. Flanagan, S. Margel, A.J. Bard, F.C. Anson, J. Am. Chem. Soc. 100 (1978) 4248-4253.

[67] X. Liu, Q.J. Ling, L. Zhao, G.R. Qiu, Y.H. Wang, L.X. Song, Y. Zhang, J. Ruiz, D. Astruc, H.B. Gu, Macromol. Rapid. Commun. 38 (2017) 1700448.

[68] G.R. Qiu, L. Zhao, X. Liu, Q.X. Zhao, F.F. Liu, Y. Liu, Y.W. Liu, H.B. Gu, React. Funct. Polym. 128 (2018) 1-8.

[69] Y. Liu, S.D. Mu, X. Liu, Q.J. Ling, C.D. Hang, J. Ruiz, D. Astruc, H.B. Gu, Tetrahedron 74 
(2018) 4777-4789.

[70] V.V. Rostovtsev, L.G. Green, V.V. Fokin, K.B. Sharpless, Angew. Chem.-Int. Edit. 41 (2002) 2596.

[71] L. Zhao, X. Liu, L. Zhang, G.R. Qiu, D. Astruc, H.B. Gu, Coord. Chem. Rev. 337 (2017) 3479.

[72] N.G. Connelly, W.E. Geiger, Chem. Rev. 96 (1996) 877-910.

[73] A.K. Diallo, J.-C. Daran, F. Varret, J. Ruiz, D. Astruc, Angew. Chem.-Int. Edit. 48 (2009) 3141-3145.

[74] A.K. Diallo, C. Absalon, J. Ruiz, D. Astruc, J. Am. Chem. Soc. 133 (2011) 629-641.

[75] H.B. Gu, R. Ciganda, P. Castel, S. Moya, R. Hernandez, J. Ruiz, D. Astruc, Angew. Chem.-Int. Edit. 57 (2018) 2204-2208.

[76] L. Zhang, G.R. Qiu, F.F. Liu, X. Liu, S.D. Mu, Y.R. Long, Q.X. Zhao, Y. Liu, H.B. Gu, React. Funct. Polym. 132 (2018) 60-73.

[77] X. Liu, G.R. Qiu, L. Zhang, F.F. Liu, S.D. Mu, Y.R. Long, Q.X. Zhao, Y. Liu, H.B. Gu, Macromol. Chem. Phys. 219 (2018) 1800273.

[78] H.J. Schneider, F. Hacket, V. Rüdiger, H. Ikeda, Chem. Rev. 98 (1998) 1755-1785.

[79] B.V.K.J. Schmidt, T. Rudolph, M. Hetzer, H. Ritter, F.H. Schacher, C. Barner-Kowollik, Polym. Chem. 3 (2012) 3139-3145.

[80] L.C. Liu, L.L. Rui, Y. Gao, W.A. Zhang, Polym. Chem. 6 (2015) 1817-1829.

[81] G. Saravanakumar, J. Kim, W.J. Kim, Adv. Sci. 4 (2017) 1600124. 
Table of content:

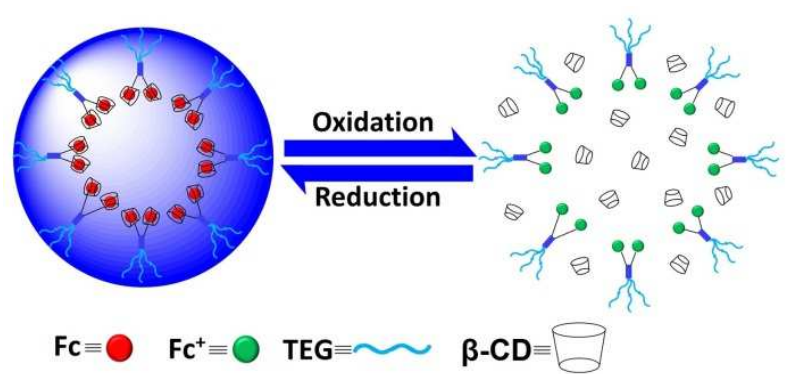

A new redox-responsive supramolecular Janus device was designed involving $\beta$-cyclodextrin and ferrocene in host-guest interaction. $\mathrm{FeCl}_{3}$ and ascorbic acid were used as oxidation and reduction triggers to modulate the self-assembly behavior in water. Substrate-loading ability was confirmed with Rhodamine B. 